Document downloaded from:

http://hdl.handle.net/10251/105854

This paper must be cited as:

Domenech-Carbo, A.; Domenech Carbo, MT.; Montagna, E.; Alvarez-Romero, C.; Lee, Y. (2017). Electrochemical discrimination of mints: The last Chinese emperors Kuang Hsu and Hsuan T'ung monetary unification. Talanta. 169:50-56. doi:10.1016/j.talanta.2017.03.025

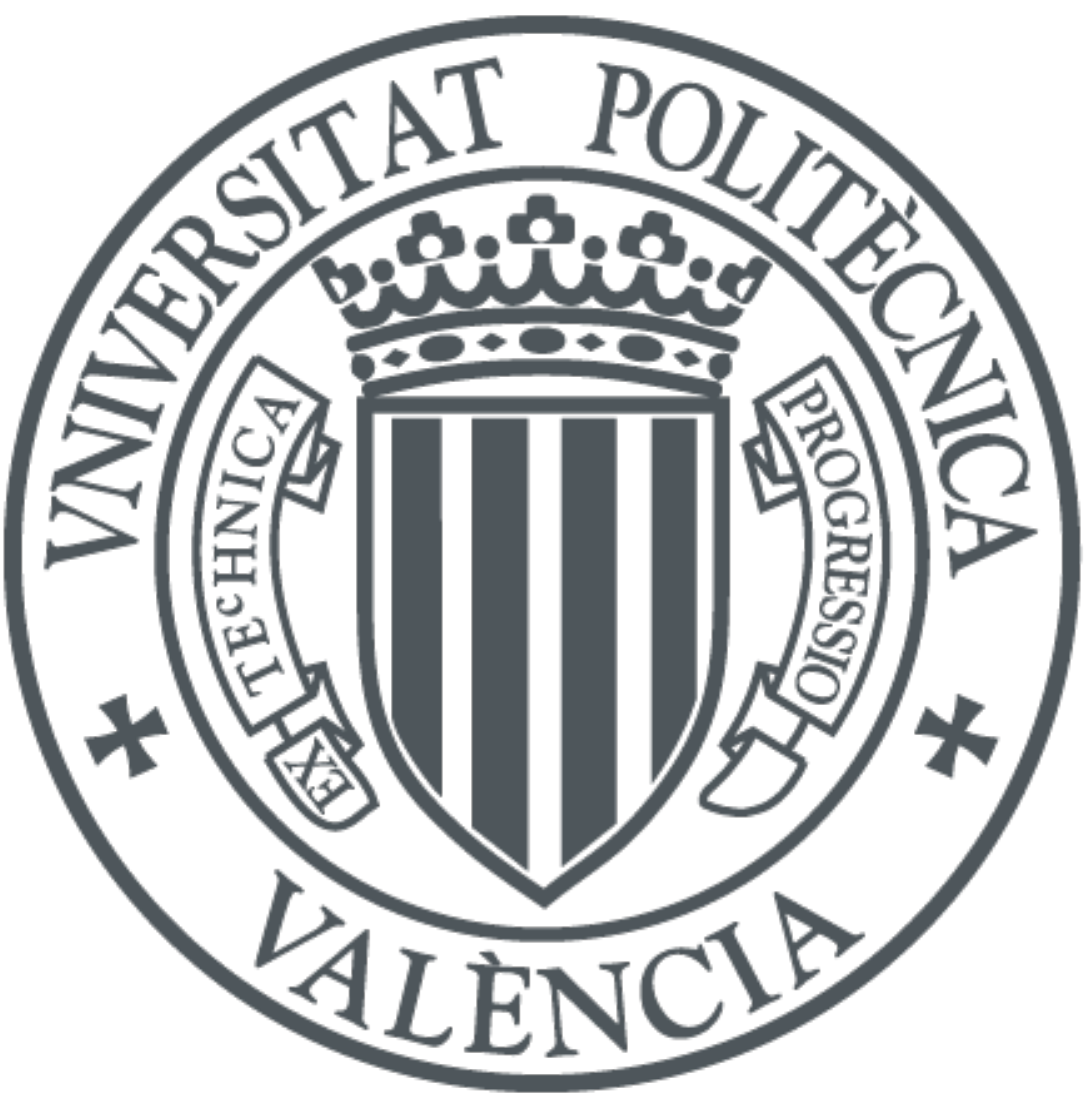

The final publication is available at

https://doi.org/10.1016/j.talanta.2017.03.025

Copyright Elsevier

Additional Information 


\title{
Electrochemical discrimination of mints: the last Chinese emperors Kuang Hsü (光 绪) and Hsüan T’ung (宣統) monetary unification
}

\author{
Antonio Doménech-Carbó*a, María Teresa Doménech-Carbób, Elena Montagna ${ }^{\mathrm{b}}$, Carla \\ Álvarez-Romero ${ }^{\mathrm{b}}, \mathrm{Yu} \mathrm{Lee}{ }^{\mathrm{c}}$ \\ ${ }^{a}$ Departament de Química Analítica. Universitat de València. Dr. Moliner, 50, 46100 \\ Burjassot (València) Spain. \\ ${ }^{\mathrm{b}}$ Institut de Restauració del Patrimoni, Universitat Politècnica de València, Camí de Vera \\ 14, 46022, València, Spain \\ ${ }^{c}$ Department. of Cultural Heritage Conservation, National Yunlin University of Science \\ and Technology, 123 University Road, 64002 Yunlin, Taiwan. \\ * Corresponding author, e-mail: antonio.domenech@uv.es \\ Tel: + 48 963543157, Fax:+ 34963544436 ,
}

\begin{abstract}
An electrochemical methodology for discriminating monetary emissions, a recurrent problem in much archaeological studies, is introduced. The method is based on the record of voltammetric signatures of cuprite and tenorite corrosion products in the patina using a minimally invasive nanosampling following the voltammetry of immobilized particles methodology. A model for the depth variation of voltammetric electrochemical parameters characterizing the composition of the corrosion patinas is presented. This model permits to rationalize electrochemical data and discriminate different monetary emissions. The application of this technique, corroborated by electrochemical impedance spectroscopy (EIS) and focusing ion beam-field emission scanning electron microscopy (FIB-FESEM-EDX), to a series of 10 cash copper coins produced around the Kuang Hsu (光绪) and Hsüan T'ung (宣統) last Chinese emperors permits to discern different provincial mints and reveals that the monetary unification developed in this period was not uniform.
\end{abstract}

Keywords: Archaeometry; Voltammetry of microparticles; Electrochemical Impedance Spectroscopy. 


\section{Introduction}

Characterizing the provenance of archaeological objects and discriminating between different production techniques and centers are obvious analytical targets. In the case of metallic artifacts, relevant information for obtaining analytical information can be derived from the chemical composition of the alloy from SEM/EDX and its microstructure from metallographic cross sections [1,2], X-ray fluorescence [3] and other spectroscopic [4,5], and diffraction [6] techniques as well as isotope analysis [7]. Several of these techniques, applied in integrative approaches [8,9], require sampling within the metal core, which is not allowed or seriously restricted for archaeological objects $[10,11]$. Accordingly, there is interest in non- or minimally invasive analytical techniques focused on the physicochemical properties of the metal patina aimed at acquire the desired archaeometric information [12-16].

In this context, the voltammetry of immobilized particles (VIMP), a solid-state electrochemical methodology developed by Scholz et al. [17-19], widely used for mineral analysis [20], was applied to obtain analytical information on archaeological materials [21]. This technique, which provides information on sparingly soluble solids attached to inert electrodes, has been applied for identifying and quantifying metals and alloys [22-25] The VIMP, using minimally invasive sampling [26,27] permits to obtain analytical information from sub-microsamples at the nanogram level of the corrosion patina of archaeological objects and was used for authentication [28] and dating lead [29] and bronze [30] archaeological artifacts.

Following this research line, we previously reported the possibility of screening coins from different provenances on the basis of empirical grouping of voltammetric data [31-33]. In order to complete such approaches, however, it is necessary to provide any theoretical justification of the observed variations in the voltammetric responses. In the current work, we report a theoretical model based on the hypothesis that the different corrosion products are differently distributed in depth in the corrosion patina. The description of the in depth distribution of corrosion products, mainly cuprite and tenorite, permits to discriminate between different mints and refine our previously 
reported VIMP-based method for dating copper/bronze [30]. VIMP experiments were carried out upon sampling a nanoscopic amount of the corrosion layers by pressing a graphite bar onto the patina of the coins and obtaining the voltammetric response of the same in contact with aqueous acetate buffer at $\mathrm{pH} 4.75$. In these conditions, and using square wave voltammetry as a detection mode, well defined responses were previously reported for copper corrosion products on sculptures and coins [31-33].

In order to support VIMP data, these were complemented by electrochemical impedance spectroscopy (EIS) and focusing ion beam-field emission scanning electron microscopy (FIB-FESEM-EDX). EIS is an electrochemical technique extensively used in the study of metal corrosion [34], which has also been applied to characterize archaeological copper/bronze artifacts [35-38]. Differing from VIMP experiments, EIS was applied to the entire coins acting as the working electrode. As the electrolyte air-saturated mineral water was used. This is a non-aggressive strategy recommended to ensure the morphological, structural and chemical integrity of the objects [39]. Following the same criterion, the reduction of dissolved oxygen acted as the redox probe [40-42].

Such techniques have been applied for discriminating different series of ten-cash Dragon copper coins minted during the reign of Kuang Hsü (光緒) (1875-1908) and Hsüan T'ung (宣統) (1906-1912), the last Qing Dynasty Chinese Emperors. It is known that such coins were, possibly, produced into one of the most chaotic monetary systems in the world, where provincial viceroys minted their own local coinage [43]. Modern locally struck coinages of the western type appeared by the first time in China in 1889 , initiated by the Viceroy Ch'ang Ch'ih-tung in Kwangtung Province. Cash coins displayed in the obverse the name of the ruling emperor in China and a flying dragon, the imperial emblem, on the reverse (See Supplementary information, Fig. 1S-4S). In the aftermath of the Mackay Treaty closing the Boxer Rebellion of 1900-01, Great Britain pressured China to create a unified coinage system and China's Qing Dynasty emperor - Kuang Hsü - and his government started a monetary reform. Although it was believed that the Board of Revenue ( $\mathrm{Hu} \mathrm{Poo}$, 戶部) acted as a central mint starting operations for producing unified currency [43], electrochemical data provide a more 
complex picture of the Chinese monetary scenario.

The study was conducted from a set of 38 ten-cash copper coins that includes coins of the Regular Provincial series minted in 9 different provinces as well as the unified Ho Poo and Tai Ching Ti Kuo (coinage under the authority of Hu Poo and Tu Chih Poo (度 支部), before and after 1906, respectively) emissions whose characteristics are summarized in Table 1 (see also Supplementary information, Table S.1 and Figs. S.1-S.4).

\section{Experimental}

\subsection{Samples}

A total of 38 ten cash Chinese coins from different mints were studied. In all cases, the coins presented a uniform light brownish patina, often with minor localized deposits of green corrosion products. The averaged composition of the base metal, determined from FIB-FESEM-EDX experiments, was $95 \pm 5 \%$ wt $\mathrm{Cu}$ plus $5 \pm 1 \%$ wt $\mathrm{Zn}$ often accompanied by traces of $\mathrm{Sn}$ and $\mathrm{Pb}$. The legends, denominations and design of the coins are provided as a Supplementary information (Table S.1).

\subsection{Electrochemical instrumentation and methods}

Electrochemical experiments were performed at $298 \mathrm{~K}$ in a three-electrode cell using a CH I660C device (Cambria Scientific, Llwynhendy, Llanelli UK). A platinum wire counterelectrode and an $\mathrm{Ag} / \mathrm{AgCl}(3 \mathrm{M} \mathrm{NaCl})$ reference electrode completed the three-electrode arrangement. Air-saturated aqueous $0.25 \mathrm{M}$ sodium acetate buffer (Panreac) at $\mathrm{pH} 4.75$ was used as a supporting electrolyte for electrochemical measurements and was renewed after each electrochemical run to avoid contamination due to metal ions eventually released to the solution phase during electrochemical turnovers. To test the possibility of using portable equipment, no deaeration was performed. Square wave voltammograms (SWVs), and cyclic voltammograms (CVs) were obtained on commercial paraffin-impregnated graphite bars (Alpino HB type, 2.0 mm diameter). 
VIMP for reference materials (cuprite and tenorite, both from Merck) was carried out using conventional VIMP protocols by powdering an amount of 1-2 $\mathrm{mg}$ of the solid in an agate mortar and pestle, and extending it on the agate mortar forming a spot of finely distributed material. Then the lower end of the graphite electrode was gently rubbed over that spot of sample and finally rinsed with water to remove ill-adhered particles. Sample-modified graphite bars were then dipped into the electrochemical cell so that only the lower end of the electrode was in contact with the electrolyte solution.

Sampling on coins for VIMP measurements was carried out by pressing a graphite bar onto the surface of the coin during $5 \mathrm{~s}$ with different intensity. This procedure ensures that an amount of products forming the corrosion patina of the coin estimated in few nanograms was abrasively transferred to the graphite surface. Then the lower end of the sample-modified graphite electrode was immersed into the electrolyte and the electrochemical runs were performed.

EIS measurements were performed using the tested coin as a working electrode upon partial immersion of the same into the electrolyte. For this purpose, the coins were suspended from an insulating tong and connected to a conventional crocodile clamp as already described [40]. For each piece, experiments were performed for three different immersion depths and varying the position of the clamp but maintaining an immersed area of ca. $1 \mathrm{~cm}^{2}$. Three repeated experiments were performed for each one of these (depth plus clamp position) configurations. Prior to each EIS experiment, an equilibration time of 10 min was taken. EIS measurements were carried out using the aforementioned instrument, in the 0.01 to $100000 \mathrm{~Hz}$ frequency range with amplitude of $10 \mathrm{mV}$ applying a bias potential of $-0.60 \mathrm{~V}$. Air-saturated mineral water from Bejís (Valencian Community, Spain) was used as a electrolyte (Composition: dry residual $159 \mathrm{mg} / \mathrm{L}, \mathrm{HCO}_{3}{ }^{-}: 163 \mathrm{mg} / \mathrm{L}, \mathrm{SO}_{4}{ }^{2-}$ : $\left.16 \mathrm{mg} / \mathrm{L}, \mathrm{Cl}^{-}: \mathrm{mg} / \mathrm{L}, \mathrm{SiO}_{2}: 4.3 \mathrm{mg} / \mathrm{L}, \mathrm{Ca}^{2+}: 47 \mathrm{mg} / \mathrm{L}, \mathrm{Mg}^{2+}: 6.2 \mathrm{mg} / \mathrm{L}, \mathrm{Na}^{+}: 2.8 \mathrm{mg} / \mathrm{L}\right)$.

\subsection{FIB-FESEM-EDX experiments}

Sectioning of trenchs and imaging of the coins in the trench were performed with a FIB-FESEM Zeiss (Orsay Physics Kleindiek Oxford Instruments) model Auriga 
compact equipment that enabled the characterization of the microtexture and mineral phases in the superficial corrosion layer and in the metal core of the ten cash copper coins. The operating conditions were: voltage, $30 \mathrm{kV}$ and current intensity, $500 \mu \mathrm{A}$ and $20 \mathrm{nA}$ in the FIB for generating the focused beam of Ga ions and a voltage of $3 \mathrm{kV}$ in the FESEM for photographs. X-ray linescans were performed in the trench operating with an Oxford-X Max X-ray microanalysis system coupled to the FESEM controlled by Aztec software. A voltage of $20 \mathrm{kV}$ and a working distance of $6-7 \mathrm{~mm}$ was used.

\section{Results and Discussion}

\subsection{Voltammetric pattern}

Figure 1 shows square wave voltammograms recorded for Honan \#01 coin attached to graphite bar in contact with air-saturated aqueous acetate buffer at $\mathrm{pH} 4.50$. Upon scanning the potential in the negative direction (Fig. 1a), a main cathode peak appears at ca. $-0.10 \mathrm{~V}\left(\mathrm{C}_{1}\right)$ which can be assigned to the reduction of cuprite $\left(\mathrm{Cu}_{2} \mathrm{O}\right)$ and several accompanying copper corrosion products such as malachite or atacamite [22-25]. In agreement with literature and previous reports [22-25,30,31-33], the above signal is accompanied by an ill-defined wave at ca. $-0.35 \mathrm{~V}\left(\mathrm{C}_{2}\right)$ which can be assigned to the reduction of tenorite $(\mathrm{CuO})$ followed by cathodic signals around $-0.70 \mathrm{~V}$ mainly attributable to the reduction of dissolved oxygen often superimposed to reductive processes of traces of lead, tin and zinc corrosion products. Upon scanning the potential in the positive direction (Fig. 1b), an anodic peak at $0.0 \mathrm{~V}\left(\mathrm{~A}_{1}\right)$ was recorded, corresponding to the oxidative dissolution of the deposit of $\mathrm{Cu}$ formed on the graphite surface as a result of the reduction of cuprite, tenorite, etc.

Figure 1 depicts three independent voltammograms for different sample-modified graphite electrodes (black, red and green lines). One can see that, although the peak profile was similar, the peak currents and the ratio between the signals $C_{1}$ and $C_{2}$ vary from one experiment to another. This feature can be attributed to the presence of a different amount of sample abrasively transferred from the coin's patina to the graphite electrode. 
Figure 2 depicts the variation of the peak current ratio (measured from the base line depicted in Figure 1a) of the signals for the reduction of tenorite and cuprite, $i\left(\mathrm{C}_{2}\right) / i\left(\mathrm{C}_{1}\right)$ with the intensity of the first peak, for Tai Ching Ti Kuo \#01 to \#10 and Hupeh \#01 to \#05 coins. One can see that the data points for each series, in spite of relatively high dispersion, fall consistently in a common curve which can be satisfactorily fitted in terms of the regression coefficient to a potential law.

Interestingly, experimental data for Chinese coins were separated from data of more ancient bronze coins, as can be seen in Figure 2, where data for a series of five coins minted in Madrid in 1661 were also plotted. Remarkably, data for these last coins corresponded to $i\left(\mathrm{C}_{2}\right) / i\left(\mathrm{C}_{1}\right)$ values clearly larger than those for Chinese coins minted ca. 1900 , in agreement with the expected increase of the tenorite to cuprite ratio on increasing the age of the objects (providing that comparable base metal and corrosion conditions operated) [30].

\subsection{Modeling in depth distribution of corrosion products}

To rationalize these features, it is pertinent to indicate that, under ordinary corrosion taking place in an atmospheric environment, corrosion of copper/bronze coins proceeds via formation of a primary patina of cuprite subsequently growing and forming a more permeable secondary patina, as described by Robbiola et al. [11-13]. Our data suggest (vide infra) that this secondary patina is progressively enriched in tenorite, whose formation from cuprite in contact with a $\mathrm{O}_{2}$-rich atmosphere is thermodynamically spontaneous $[44,45]$.

Then, and consistently with FIB-FESEM-EDX experiments (vide infra) and studies on bronze patinas [46] and artificial copper oxide thin films [47], one can assume that in the studied coins there is a thin primary patina of cuprite covered by a thick, porous secondary patina mainly constituted by a mixture of cuprite and tenorite microcrystals whose composition varies with the depth $z$. During the sampling process, the graphite electrode was pressed onto the coin patina so that the net volume of metal oxide particles of the secondary patina transferred to the electrode surface, $V$, will vary with the depth reaching in that process as $\mathrm{d} V=S \mathrm{~d} z$. (see scheme presented as a 
Supplementary information, Figure S.5). Since in different sampling steps on the same coin different deep was attained by the graphite bar, the resulting microparticulate deposits whose voltammetric response was recorded were representative of the composition of more or less deep regions of the secondary patina of the coin. Thus, one can expect that the upper corrosion layers are enriched in tenorite relative to the deep ones. Accordingly, there is a concentration gradient of tenorite in the corrosion layers so that the tenorite/cuprite ratio will be larger when sampling is carried out in the external region than when sampling is performed in deeper layers. Although layer-by-layer voltammetric measurements were in principle possible, via controlled abrasion or electrochemical erosion [48] of the corrosion layers, only the described 'smooth' sampling was used in order to minimize the intervention over the coins, as demanded by conservators and restorers.

Now, let us assume that the number of tenorite grains per volume unit, $n_{\text {ten }}$, decreases following a potential law with the depth while the number of cuprite grains per volume unit, $n_{\text {cup }}$, increases so that the total number of copper oxide particles per volume unit, $n$, remains constant. Then, $n_{\text {ten }}=n_{\text {ten }}^{\text {sup }} z^{a} ; n_{\text {cup }}=n_{\text {cup }}^{\text {sup }}+n_{\text {ten }}^{\text {sup }}\left(1-z^{\alpha}\right)$, where $n_{\text {cup }}^{\text {sup }}, n_{\text {ten }}^{\text {sup }}$, represent the surface number of cuprite and tenorite grains, respectively. Under fixed electrochemical conditions, the currents measured for the voltammetric peaks of cuprite and tenorite reduction, $i\left(\mathrm{C}_{1}\right), i\left(\mathrm{C}_{2}\right)$, should be proportional to the total number of cuprite and tenorite grains extracted from the corrosion layers during the sampling process. Accordingly,

$$
\begin{aligned}
& i\left(\mathrm{C}_{2}\right)=\int_{0}^{z} \varepsilon_{\text {ten }} n_{\text {ten }}^{\text {sup }} S z^{\alpha} d z \\
& i\left(\mathrm{C}_{1}\right)=\int_{0}^{z} \varepsilon_{\text {cup }} S\left[n_{\text {cup }}^{\text {sup }}+n_{\text {ten }}^{\text {sup }}\left(1-z^{\alpha}\right) d z\right.
\end{aligned}
$$

Here, $\varepsilon_{\text {cup }}, \varepsilon_{\text {ten }}$, represent electrochemical constants characterizing the respective reduction processes of cuprite and tenorite, only depending on the electrochemical conditions (electrolyte, temperature, potential scan rate, etc.). When $\alpha$ was close to -1 , 
integration of the above equations yields:

$$
\frac{i_{\text {ten }}}{i_{\text {cup }}}=\frac{i\left(\mathrm{C}_{2}\right)}{i\left(\mathrm{C}_{1}\right)}=\frac{\varepsilon_{\text {ten }} n_{\text {ten }}^{\text {sup }}}{\varepsilon_{\text {cup }}}\left(\frac{z^{1+\alpha}}{(1+\alpha) n z+n_{\text {ten }}^{\text {sup }} z^{1+\alpha}}\right)
$$

where $\mathrm{n}=n_{\text {cup }}^{\text {sup }}+n_{\text {ten }}^{\text {sup }}$. Assuming that $(1+\alpha) n z \gg n_{\text {ten }}^{\text {sup }} z^{1+\alpha}$ and approximating $\mathrm{z}=$ $\left.i(\mathrm{C} 1) / \varepsilon_{\text {cup }} S n\right)$ yields:

$$
\frac{i\left(\mathrm{C}_{2}\right)}{i\left(\mathrm{C}_{1}\right)} \approx \frac{\varepsilon_{\text {ten }} n_{\text {ten }}^{\text {sup }}}{(1+\alpha) \varepsilon_{\text {cup }}^{1+\alpha} n^{1+\alpha} S^{\alpha}} i\left(\mathrm{C}_{1}\right)^{\alpha}=A\left(C_{1}\right)^{\alpha}
$$

This equation predicts a potential relationship between the $i\left(\mathrm{C}_{2}\right) / i\left(\mathrm{C}_{1}\right)$ ratio and $i\left(\mathrm{C}_{1}\right)$ which can be experimentally tested. Conceivably, the parameters $n_{\text {ten }}^{\text {sup }}, n_{\text {cup }}^{\text {sup }}, \alpha, \varepsilon_{\text {ten }}, \varepsilon_{\text {cup }}$ and $S$ will be the same for each series of coins, although they can vary from one mint to another.

Consistently, plots of $\log \left[i\left(\mathrm{C}_{2}\right) / i\left(\mathrm{C}_{1}\right)\right]$ vs. $\log \left[i\left(\mathrm{C}_{1}\right)\right]$ provided straight lines of different slopes (see Table 2) but tending to a common ordinate at the origin as can be seen in Figure 3. One can see in this figure how the set of the studied ten-cash Dragon copper coins can be grouped in four electrochemical types labeled as type I (Tai Ching Ti Kuo \#01 to \#10) and Tsingkiang, type II (Anhwei and Hupeh), type III (Hu Poo, Peiyang, Honan, Kiangsi and Kiangnan) and type IV (Kwangtung, and Hunan). Interestingly, the data point for coin Tai Ching Ti Kuo \#11 falls in the region of type II coins.

\subsection{Electron microscopy analysis}

In order to explore the reasons for the above mint-characteristic differences in the electrochemical response of coins, FIB-FESEM-EDX experiments using a Ga ions microbeam were performed. This technique can be considered as micro-invasive as the ionic microbeam yields trenches which size is lower than $10 \mu \mathrm{m}$ not detectable at the macroscopic level. Figure 4 shows the secondary electron images of trench $c a .10 \mu \mathrm{m}$ length and $c a .15 \mu \mathrm{m}$ depth generated by FIB in the region of interest in the coins $\mathrm{Hu}$ 
Poo \#02 and Tai Ching Ti Kuo \#09. In both cases, the obtained trench extends from the outer corrosion layers down to the metal core of the coin. Remarkably, not only the texture of the corrosion layer in the upper region of the trench, but also the grained microtexture of the metal core of the coins appears as different. The metal core exhibits abundant facets of columnar habit overlapped with larger domains in the case of $\mathrm{Hu}$ Poo coins whereas the section of the Tai Ching Ti Kuo coins shows a network of large angular domains.

Additionally, coupling EDX analysis to FIB-FESEM imaging permits to determine the composition of the core metal and the layer by layer composition of the corroded region Figure 5 depicts the variation of the $\mathrm{Cu}$ content with the depth $(z)$ determined from FESEM-EDX data for coins representative of each one of the aforementioned electrochemical types. There are differences in the concentration gradient in the external $(0<z<3 \mu \mathrm{m})$ region of the trenches which, in principle, would be illustrative of the existence of different corrosion patterns, but these were mainly attributable to the different corrosion history of individual coins. The most clear regularity, however, was observed in the copper content in the metal core (see inset in Figure 5). Averaged values from measurements in three different coins of each one of the electrochemical types I-IV suggested an increase of the $\mathrm{Cu}$ content from series I to IV.

In order to test the above modeling with FIB-FESEM-EDX data, the depth variation of the 'absolute' concentration of copper was probably the most robust parameter. Let us assume that the decrease of $\mathrm{Cu}$ concentration is due exclusively to the formation of cuprite and tenorite. This is an obvious oversimplification especially when strong corrosion exists so that a tertiary patina is formed. However, for smooth corrosion, the number of copper crystals per volume unit in the secondary patina, $n_{\mathrm{Cu}}$, existing at a depth $z$ should satisfy the relationship:

$$
n_{\mathrm{Cu}}=n_{\mathrm{Cu}}^{\mathrm{o}}-n_{\mathrm{ten}}-2 n_{\mathrm{cup}}=n_{\mathrm{Cu}}^{\mathrm{o}}-n_{\mathrm{ten}}^{\mathrm{sup}}(\delta-z)^{\alpha}-n_{\mathrm{cup}}^{\mathrm{o}}+2 n_{\mathrm{ten}}^{\mathrm{sup}}(\delta-z)^{\alpha}
$$

where $n_{C u}^{o}$ denotes the copper concentration at the base metal. Accordingly, the 
variation of the ratio between the copper concentration at a depth $z$ and the maximum copper concentration will be:

$$
\frac{n_{\mathrm{Cu}}}{n_{\mathrm{Cu}}^{\mathrm{o}}}=\frac{n_{\mathrm{Cu}}^{\mathrm{o}}-n_{\mathrm{cup}}^{\mathrm{o}}+n_{\mathrm{ten}}^{\mathrm{sup}}(\delta-z)^{\alpha}}{n_{\mathrm{Cu}}^{\mathrm{o}}}=1-\frac{n_{\mathrm{cup}}^{\mathrm{o}}}{n_{\mathrm{Cu}}^{\mathrm{o}}}+\frac{n_{\mathrm{ten}}^{\mathrm{sup}}}{n_{\mathrm{Cu}}^{\mathrm{o}}}(\delta-z)^{\alpha}
$$

which corresponds to a potential increase with depth. Experimental FIB-FESEM data agreed (see Figure 6) with this theoretical model. Accordingly, one can assume that the differences observed in the voltammetric response are attributable to the different corrosion pattern resulting, presumably, from the different chemical composition and, mainly, microcyrstalline structure of the base metal, in turn resulting from possible differences in the raw material, dosification and, mainly, the thermomechanical process used in the fabrication of the coins.

\subsection{Impedance analysis}

In order to corroborate the above ideas, EIS experiments were performed using air-saturated mineral water as a non-aggressive electrolyte [39] and the reduction of dissolved oxygen which acts as a redox probe [40-42]. Figure 7 compares the experimental data for coins of the types I and IV. The Nyquist plots consist of a depleted capacitive loop slightly distorted at high frequencies whereas the Bode plots present two maxima in the phase angle at high and intermediate frequencies. These spectra can be described in terms of equivalent circuits analogue to those previously reported [40-42] comprising two parallel combinations of resistance and constant phase elements roughly representative of charge transfer and charge separation through/in the electrolyte/corrosion layer and corrosion layer/metal core interfaces.

As can be seen in Figure 7, the obtained impedance spectra varied in successive measurements on the same coin (black, red and green data points), presumably as a result of surface hydration/equilibration [41]. Accordingly, different sets of values of the impedance parameters were obtained for each coin. Pairs of such parameters, however, were grouped defining tendency lines in the corresponding two-parameter 
representations. For simplicity an empirical correlation between the maximum phase angle at middle frequencies, $\varphi_{\mathrm{m}}$, and the frequency at which this maximum appears, $f_{\mathrm{m}}$ was taken for grouping different coins. Pertinent data can be seen in Figure 8, where one can see that coins of the previous VIMP groups I, II and III fall around lightly separated tendency lines in the $-\varphi_{\mathrm{m}} \mathrm{vs} . \log \left(f_{\mathrm{m}}\right)$ diagram. The coins of the group IV, were apparently divided into those from Kwangtung, which are close to groups I-III and those from Hunan. As observed in the case of VIMP grouping, the coin Tai Ching Ti Kuo \#11 was close to the coins of types II and III. For our purposes, the relevant point to emphasize is that an essentially consistent electrochemical grouping was obtained from two independent techniques.

\subsection{Archaeometric implications}

The obtained electrochemical grouping can be correlated with geographical and temporal data (see Supplementary information, Fig. S.6) and can be summarized as:

a) Type I was used in the Tsingkiang mint and was coincident to the Tai Ching Ti Kuo unified production. The latter was divided into the Board of Revenue (Hu Poo) and different provincial sub-series (Hupeh, Hunan, Anwhei, Kiangnan and Ssûch'uan (Szechwan)), one of which (Kiangnan) corresponded to the type III, (see Supplementary information, Fig. S.7) thus suggesting that the presumed unification was only partial.

b) Type II was minted in the central provinces of Hupeh and Anhwei.

c) Type III was minted in the central provinces of Honan, Kiangnan and Kiangsi and was coincident with the unified series labeled here as Hu Poo and Peiyang mint.

d) Type IV was produced in the southern provinces of Hunan and Kwantung. Since the modern monetary production started in Kwantung in 1889, this type can be considered as the precedent of all other series.

Accordingly, electrochemical data confirm the idea that independent-like provincial mints operated before the monetary unification. Experimental data for coins of the Tai Ching Ti Kuo series, where several mints were used, are provided as a Supplementary material, Fig. S6. Although possibly with light variations between them, coins with no 
mint indication and those from Hupeh, Ssûch'uan (Szechwan) and Kwantung mints fall in a common potential line in the $i\left(\mathrm{C}_{2}\right) / i\left(\mathrm{C}_{1}\right)$ vs. $i\left(\mathrm{C}_{1}\right)$ diagram. However, Tai Ching Ti Kuo coins from Kiangnan deviate clearly from the above tendency and fall in the line corresponding to the production of regular provinces of type III (Honan, Kiangnan and Kiangsi, see also Fig. 3).

Such data indicate that, contrary to the idea that a complete renewal of the monetary production accompanied the unification, the initial production of unified currency $(\mathrm{Hu}$ Poo series), followed the production pattern of the central provinces Honan, Kiangnan and Kiangsi (type III). This mode would be changed for producing the unified series (Tai Ching Ti Kuo, type I). Our results clearly suggest that the unified mode of production was changed between 1905 and 1906. In fact, the experimental data points for one of the Tai Ching Ti Kuo coins (\#11) were clearly separated from the type I in the diagrams depicted in Figures 2, 3 and 8. A reasonable hypothesis is that the Tai Ching Ti Kuo was initiated following one of the previous provincial modes but that the production was early modified. In fact, the coins of the Tai Ching Ti Kuo series, contrary to the presumed unification, were prepared in several mints and at least one of which (Kiangnan, see Figures 3 and S6) was fabricated following precedent procedures. These data are indicative that the imperial monetary unification was stepwise and partial.

An additional aspect to underline is that data in Figs. 2 and 3, denoting that the tenorite/cuprite ratio is sensitive to the depth of sampling and the composition and thermomechanical mode of preparation of the metal, are also of interest in regard to the previously described electrochemical dating of copper/bronze objects $[30,42]$. Such data suggest that the $\alpha$-exponent in Eq. (3) is quite sensitive to the composition and thermomechanical treatment of the alloy whereas the $A$-coefficient, which is representative of the tenorite/cuprite ratio at the more external region of the corrosion layer, would be representative of the corrosion time (under uniform and common conditions of aging) and much less sensitive to the thermomechanical mode of preparation. A-values for the Spanish maravedis $(6.39 \pm 0.04)$, the four series of Chinese 
coins studied here (averaged value, $2.90 \pm 0.15$ ), and eurocent coins $(2.08 \pm 0.11$ ), are in agreement with this idea. Accordingly, A-data can provide a refined age estimate relative to that based on an averaged estimate of that ratio [30] but further series of data have to be considered for this purpose.

\section{Conclusions}

Using minimally invasive sampling, the voltammetry of microparticles methodology yields well-defined voltammetric responses for nanosamples of the patina of coins displaying characteristic features of cuprite and tenorite. The depth variation of the relative intensity of tenorite and cuprite signals can be modeled using a potential law which is in agreement with experimental voltammetric data and EDX analysis and is also consistent with data from EIS. Application of such techniques to a series of 10 cash copper coins produced around the Kuang Hsu (光绪) Chinese emperor last monetary unification provided the discrimination of different mints based on characteristic voltammetric and impedance features. The differences in the voltammetric response can be associated, in agreement with FIB-FESEM-EDX examination of coins, to subtle mint-characteristic differences in the composition and thermomechanical processing of the base alloy. Accordingly, characteristic depth-depending electrochemical data are usable for discrimination of monetary series and refining electrochemical dating of copper/bronze objects, thus providing a complementary tool for numismatic and archaeological studies.

Acknowledgements. Financial support from the Spanish MINECO Projects CTQ2014-53736-C3-1-P and CTQ2014-53736-C3-2-P which are also supported with ERDF funds. The Universita degli Studi di roma "La Sapienza" has granted a six-months research-scholarship to the graduated Elena Montagna. The authors also wish to thank Dr. José Luis Moya López and Mr. Manuel Planes Insausti (Microscopy Service of the Universitat Politècnica de València) for technical support. 


\section{References}

[1] D. Attanasio, G. Bultrini, G.M Ingo, Archaeometry, 43 (2001) 529-547.

[2] J.V. Gimeno-Adelantado, M.A. Ferrer-Eres, F.M. Valle-Algarra, J. Peris-Vicente, F. Bosch-Reig. Talanta 60 (2003) 895-910.

[3] S. Shalev, S. Sh. Shilstein, Yu Yekutieli, Talanta 70 (2006) 909-913.

[4] R. Gaudiuso, M. Dell'Aglio, O. De Pascale, S. Loperfido, A. Mangone, A. Anal. Chim. Acta 813 (2014) 15-24.

[5] S. Guirado, F.J. Fortes, J.J. Laserna, Talanta 137 (2015) 182-188.

[6] A. Duran, L.K. Herrera, M.C. Jimenez de Haro, A. Justo, J.L. Perez-Rodriguez, Talanta 76 (2008) 183-188.

[7] P. Budd, D. Gale, A.M. Pollard, R.G. Thomas, P.A. Williams, Archaeometry 35 (1993) 241-247.

[8] E. Ribechini, F. Modugno, C. Baraldi, P. Baraldi, M.P. Colombini, Talanta 74 (2008) $555-561$.

[9] M. Tomassetti, F. Marini, R. Bucci, L. Campanella, Trends in Analytical Chemistry, 79 (2016) 371-379.

[10] D.A. Scott, Journal of the American Institute of Conservation 33 (1994) 1-23.

[11] L. Robbiola, J.M. Blengino, C. Fiaud, Corros. Sci. 40 (1998) 2083-2111.

[12] L. Robbiola, R. Portier, J. Cult. Herit. 7 (2006) 1-12.

[13] C. Chiavari, K. Rahmouni, H. Takenouti, S. Joiret, P. Vermaut L. Robbiola, Electrochim. Acta 52 (2007) 7760-7769.

[14] I. Constantinides, A. Adriaens, F. Adams, Appl. Surf. Sci. 189 (2002) 90-101.

[15] I. De Ryck, A. Adriaens, E. Pantos, F. Adams, Analyst 128 (2003) 1104-119.

[16] M.C. Bernard, S. Joiret, Electrochim. Acta 54 (2009) 5199-5205.

[17] F. Scholz, B. Meyer, Voltammetry of solid microparticles immobilized on electrode surfaces. Electroanalytical Chemistry, A Series of Advances. Bard, A. J., and Rubinstein, I., Eds., Marcel Dekker, New York 20 (1998) 1-86.

[18] F. Scholz, U. Schröder, R. Gulaboski, A. Doménech-Carbó, Electrochemistry of Immobilized Particles and Droplets. $2^{\text {nd }}$ Edit. Springer, Berlin-Heidelberg (2014). 
[19] A. Doménech-Carbó, J. Labuda, F. Scholz, Pure Appl. Chem. 85 (2013) 609-631 (IUPAC Technical Report).

[20] Y. Niu, F. Sun, Y. Xu, Z. Cong, E. Wang. Talanta 127 (2014) 211-218.

[21] A. Doménech-Carbó, M. T. Doménech-Carbó, V. Costa, Electrochemical Methods in Archaeometry, Conservation and Restoration. Monographs in Electrochemistry Series, Scholz, F., Ed. Springer, Berlin-Heidelberg (2009).

[22] M. Serghini-Idrissi, M.C. Bernard, F.Z. Harrif, S. Joiret, K. Rahmouni, A. Srhiri, H. Takenouti, V. Vivier, M. Ziani, Electrochim. Acta 50 (2005) 4699-4709.

[23] V. Costa, K. Leyssens, A. Adriaens, N. Richard, F. Scholz, J. Solid State Electrochem. 14 (2010) 449-451.

[24] D. Satovic, S. Martinez, A. Bobrowski, Talanta 81 (2010) 1760-1765.

[25] F.A. Gholenji, A. Adriaens, J. Solid State Electrochem. 16 (2012) 535-543.

[26] D. Blum, W. Leyffer, R. Holze, Electroanalysis 8 (1996) 296-297.

[27] A. Doménech-Carbó, M.T. Doménech-Carbó, M.A. Peiró-Ronda, Electroanalysis 23 (2011) 1391-1400.

[28] A. Doménech-Carbó, M.T. Doménech-Carbó, M.T., Peiró-Ronda, M.A., L. Osete-Cortina, Archaeometry 53 (2011) 1193-1211.

[29] A. Doménech-Carbó, M.T. Doménech-Carbó, M.A. Peiró-Ronda, Anal. Chem. 83 (2011) 5639-5644.

[30] A. Doménech-Carbó, M.T. Doménech-Carbó, S. Capelo, T. Pasíes, I. Martínez-Lázaro, Angew. Chem. Int. Ed. 53 (2014) 9262-9266.

[31] A. Doménech-Carbó, M.T. Doménech-Carbó, T. Pasíes, M.C. Bouzas. Electroanalysis 24 (2012) 1945-1955.

[32] A. Doménech-Carbó, J. Del Hoyo-Menéndez, M.T. Doménech-Carbó, J. Piquero-Cilla, Microchem. J. 130 (2017) 47-55.

[33] F. Di Turo, N. Montoya, J. Piquero-Cilla, C. De Vito, F. Coletti, G. Favero, A. Doménech-Carbó, Anal. Chim. Acta 955 (2017) 36-47.

[34] D.D. Macdonald, Electrochim. Acta 56 (2011)1761-1772.

[35] N. Souissi, L. Bousselmi, S. Khosrof, E. Triki, Mater. Corros. 55 (2004) 284-292. 
[36] N. Souissi, E. Triki, Mater. Corros. 60 (2009) 262-268.

[37] A.L. Mata, M.M.L. Salta, M.M.M. Neto, M.H. Mendonça, I.T.E. Fonseca, Mater. Corros. 61 (2010) 205-210.

[38] E. Cano, D. Lafuente, D.M. Bastidas, J. Solid State Electrochem. 14 (2010) 381-391.

[39] C. DeGrigny, G. Guibert, S. Ramseyer, G. Rapp, A. Tarchini, J. Solid State Electrochem. 14 (2010) 425-436.

[40] A. Doménech-Carbó, M.T. Doménech-Carbó, M.A. Peiró-Ronda, I. Martínez-Lázaro, J. Barrio, J. Solid State Electrochem. 16 (2012) 2349-2356.

[41] A. Doménech-Carbó, M. Lastras, F. Rodríguez, L. Osete-Cortina, J. Solid State Electrochem. 18 (2014) 399-409.

[42] A. Doménech-Carbó, S. Capelo, J. Piquero-Cilla, M.T. Doménech-Carbó, J. Barrio, A. Fuentes, W. Al-Sekkaneh. Mater. Corros. 67 (2016) 120-129.

[43] A.M. Tracey Woodward, The minted ten-cash coins of China, M.R. Fried Publ. Oakland (1971).

[44] D.A. Scott, Stud. Conservat. 42 (1997) 93-100.

[45] M.T. S. Nair, L. Guerrero, O.L. Arenas, P.K. Nair, Appl. Surf. Sci. 150 (1999) $143-151$.

[46] P. Ropret, T. Kosec, J. Raman Spectrosc. 43 (2012) 1578-1586.

[47] H. Stein, D. Naujoks, D. Grochla, C. Khare, R. Gutwoski, S. Grützke, W. Schuhmann, A. Ludwig, Phys. Status Solidi A 212 (2015) 2798-2804.

[48] A. Doménech-Carbó, M.T. Doménech-Carbó, I. Martínez-Lázaro, Anal. Chim. Acta $680(2010) 1-9$. 
Figures

Figure 1. Square wave voltammograms (black, red and green lines correspond to three independent measurements at freshly sample-modified electrodes) of samples from coin Honan \#01 attached to graphite bar immersed into air-saturated $0.25 \mathrm{M} \mathrm{HAc/NaAc}$ aqueous buffer, $\mathrm{pH} 4.50$. Potential scan initiated a) at $+0.75 \mathrm{~V}$ in the negative direction and b) $-0.75 \mathrm{~V}$ in the positive direction. Potential step increment $4 \mathrm{mV}$; square wave amplitude $25 \mathrm{mV}$; frequency $5 \mathrm{~Hz}$. Horizontal dotted lines represent the base lines for peak current measurements. Inset: photographic image of the obverse (left) and reverse (right) coin.

Figure 2. Variation of the $i\left(\mathrm{C}_{2}\right) / i\left(\mathrm{C}_{1}\right)$ ratio on $i\left(\mathrm{C}_{1}\right)$ for Tai Ching Ti Kuo and Hupeh coins and Spanish maravedis minted in Madrid in 1661. Independent measurements for three samples of each coin from voltammograms such as in Figure 1. Continuous lines correspond to the fit of each series of data to a potential law. Bars correspond to estimated uncertainties of $\pm 10 \%$.

Figure 3. Variation of $\log \left[i\left(\mathrm{C}_{2}\right) / i\left(\mathrm{C}_{1}\right)\right]$ on $\log \left[i\left(\mathrm{C}_{1}\right)\right]$ for the 10 cash Dragon copper coins studied here and electrochemical grouping of the different series. Circles correspond to data for the coin Tai Ching Ti Kuo \#11.

Figure 4. Secondary electron images of trench $c a .10 \mu \mathrm{m}$ length and $c a .15 \mu \mathrm{m}$ depth generated by FIB in the region of interest in the coins: a,b) Hu Poo \#02 and c,d) Tai Ching Ti Kuo \#09 coins at two different magnifications.

Figure 5. Variation of the $\mathrm{Cu}$ content with the depth $(z)$ determined from FIB-FESEM-EDX data for coins Tai Ching Ti Kuo \#06 (grey rhombs), Anhwei \#01 (grey squares), Hu Poo \#01 (rhombs) and Hunan \#01 (black squares). Inset: interval of copper content values in the metal core from measurements in three different coins of each one of the electrochemical types I-IV. 
Figure 6. Depth variation of the $\% \mathrm{Cu} / \% \mathrm{Cu}(\max )$ ratio determined from FIB-FESEM-EDX data for Hu Poo \#01 (squares) and Hunan \#01 (solid squares) coins. When the primary patina was reached, the proportion of $\mathrm{Cu}$ remained essentially constant. Curved lines correspond to data fitting to a potential law.

Figure 7. EIS of coins a,b) Kwantung \#02 and c,d) Tai Ching Ti Kuo \#06 in contact with air-saturated mineral water. a,c) Bode plots of -(phase angle) vs. $\log ($ frequency) and b,d) Nyquist plots of $-Z_{\text {imag }}$ vs. $Z_{\text {real }}$. Bias potential $-0.60 \mathrm{~V}$. Black, red and green data points correspond to three successive EIS measurements on the same coin.

Figure 8. Variation of $-\varphi_{\mathrm{m}}$ on $\log \left(f_{\mathrm{m}}\right)$ in EIS of the studied coins in conditions such as in Figure 6. Three successive measurements were superimposed for each coin. Continuous lines correspond to the fit of each series of data to a potential law. Circles correspond to data for the coin Tai Ching Ti Kuo \#11. 
Electrochemical discrimination of mints: the last Chinese emperors Kuang Hsü (光 绪) and Hsüan T’ung (宣統) monetary unification

Antonio Doménech-Carbó*a, María Teresa Doménech-Carbób, Elena Montagna ${ }^{\mathrm{b}}$, Carla Álvarez-Romero ${ }^{\mathrm{b}}, \mathrm{Yu} \mathrm{Lee}^{\mathrm{c}}$

a Departament de Química Analítica. Universitat de València. Dr. Moliner, 50, 46100 Burjassot (València) Spain.

${ }^{\mathrm{b}}$ Institut de Restauració del Patrimoni, Universitat Politècnica de València, Camí de Vera 14, 46022, València, Spain

${ }^{c}$ Department. of Cultural Heritage Conservation, National Yunlin University of Science and Technology, 123 University Road, 64002 Yunlin, Taiwan.

* Corresponding author, e-mail: antonio.domenech@uv.es

Tel: + 48 963543157, Fax:+ 34963544436 ,

\begin{abstract}
An electrochemical methodology for discriminating monetary emissions, a recurrent problem in much archaeological studies, is introduced. The method is based on the record of voltammetric signatures of cuprite and tenorite corrosion products in the patina using a minimally invasive nanosampling following the voltammetry of immobilized particles methodology. A model for the depth variation of voltammetric electrochemical parameters characterizing the composition of the corrosion patinas is presented. This model permits to rationalize electrochemical data and discriminate different monetary emissions. The application of this technique, corroborated by electrochemical impedance spectroscopy (EIS) and focusing ion beam-field emission scanning electron microscopy (FIB-FESEM-EDX), to a series of 10 cash copper coins produced around the Kuang Hsu (光绪) and Hsüan T'ung (宣統) last Chinese emperors permits to discern different provincial mints and reveals that the monetary unification developed in this period was not uniform.
\end{abstract}

Keywords: Archaeometry; Voltammetry of microparticles; Electrochemical Impedance Spectroscopy. 


\section{Introduction}

Characterizing the provenance of archaeological objects and discriminating between different production techniques and centers are obvious analytical targets. In the case of metallic artifacts, relevant information for obtaining analytical information can be derived from the chemical composition of the alloy from SEM/EDX and its microstructure from metallographic cross sections [1,2], X-ray fluorescence [3] and other spectroscopic [4,5], and diffraction [6] techniques as well as isotope analysis [7]. Several of these techniques, applied in integrative approaches [8,9], require sampling within the metal core, which is not allowed or seriously restricted for archaeological objects $[10,11]$. Accordingly, there is interest in non- or minimally invasive analytical techniques focused on the physicochemical properties of the metal patina aimed at acquire the desired archaeometric information [12-16].

In this context, the voltammetry of immobilized particles (VIMP), a solid-state electrochemical methodology developed by Scholz et al. [17-19], widely used for mineral analysis [20], was applied to obtain analytical information on archaeological materials [21]. This technique, which provides information on sparingly soluble solids attached to inert electrodes, has been applied for identifying and quantifying metals and alloys [22-25] The VIMP, using minimally invasive sampling [26,27] permits to obtain analytical information from sub-microsamples at the nanogram level of the corrosion patina of archaeological objects and was used for authentication [28] and dating lead [29] and bronze [30] archaeological artifacts.

Following this research line, we previously reported the possibility of screening coins from different provenances on the basis of empirical grouping of voltammetric data [31-33]. In order to complete such approaches, however, it is necessary to provide any theoretical justification of the observed variations in the voltammetric responses. In the current work, we report a theoretical model based on the hypothesis that the different corrosion products are differently distributed in depth in the corrosion patina. The description of the in depth distribution of corrosion products, mainly cuprite and tenorite, permits to discriminate between different mints and refine our previously 
reported VIMP-based method for dating copper/bronze [30]. VIMP experiments were carried out upon sampling a nanoscopic amount of the corrosion layers by pressing a graphite bar onto the patina of the coins and obtaining the voltammetric response of the same in contact with aqueous acetate buffer at $\mathrm{pH} 4.75$. In these conditions, and using square wave voltammetry as a detection mode, well defined responses were previously reported for copper corrosion products on sculptures and coins [31-33].

In order to support VIMP data, these were complemented by electrochemical impedance spectroscopy (EIS) and focusing ion beam-field emission scanning electron microscopy (FIB-FESEM-EDX). EIS is an electrochemical technique extensively used in the study of metal corrosion [34], which has also been applied to characterize archaeological copper/bronze artifacts [35-38]. Differing from VIMP experiments, EIS was applied to the entire coins acting as the working electrode. As the electrolyte air-saturated mineral water was used. This is a non-aggressive strategy recommended to ensure the morphological, structural and chemical integrity of the objects [39]. Following the same criterion, the reduction of dissolved oxygen acted as the redox probe [40-42].

Such techniques have been applied for discriminating different series of ten-cash Dragon copper coins minted during the reign of Kuang Hsü (光緒) (1875-1908) and Hsüan T'ung (宣統) (1906-1912), the last Qing Dynasty Chinese Emperors. It is known that such coins were, possibly, produced into one of the most chaotic monetary systems in the world, where provincial viceroys minted their own local coinage [43]. Modern locally struck coinages of the western type appeared by the first time in China in 1889 , initiated by the Viceroy Ch'ang Ch'ih-tung in Kwangtung Province. Cash coins displayed in the obverse the name of the ruling emperor in China and a flying dragon, the imperial emblem, on the reverse (See Supplementary information, Fig. 1S-4S). In the aftermath of the Mackay Treaty closing the Boxer Rebellion of 1900-01, Great Britain pressured China to create a unified coinage system and China's Qing Dynasty emperor - Kuang Hsü - and his government started a monetary reform. Although it was believed that the Board of Revenue ( $\mathrm{Hu}$ Poo, 戶部) acted as a central mint starting operations for producing unified currency [43], electrochemical data provide a more 
complex picture of the Chinese monetary scenario.

The study was conducted from a set of 38 ten-cash copper coins that includes coins of the Regular Provincial series minted in 9 different provinces as well as the unified Ho Poo and Tai Ching Ti Kuo (coinage under the authority of Hu Poo and Tu Chih Poo (度 支部), before and after 1906, respectively) emissions whose characteristics are summarized in Table 1 (see also Supplementary information, Table S.1 and Figs. S.1-S.4).

\section{Experimental}

\subsection{Samples}

A total of 38 ten cash Chinese coins from different mints were studied. In all cases, the coins presented a uniform light brownish patina, often with minor localized deposits of green corrosion products. The averaged composition of the base metal, determined from FIB-FESEM-EDX experiments, was $95 \pm 5 \%$ wt $\mathrm{Cu}$ plus $5 \pm 1 \%$ wt $\mathrm{Zn}$ often accompanied by traces of $\mathrm{Sn}$ and $\mathrm{Pb}$. The legends, denominations and design of the coins are provided as a Supplementary information (Table S.1).

\subsection{Electrochemical instrumentation and methods}

Electrochemical experiments were performed at $298 \mathrm{~K}$ in a three-electrode cell using a CH I660C device (Cambria Scientific, Llwynhendy, Llanelli UK). A platinum wire counterelectrode and an $\mathrm{Ag} / \mathrm{AgCl}(3 \mathrm{M} \mathrm{NaCl})$ reference electrode completed the three-electrode arrangement. Air-saturated aqueous $0.25 \mathrm{M}$ sodium acetate buffer (Panreac) at $\mathrm{pH} 4.75$ was used as a supporting electrolyte for electrochemical measurements and was renewed after each electrochemical run to avoid contamination due to metal ions eventually released to the solution phase during electrochemical turnovers. To test the possibility of using portable equipment, no deaeration was performed. Square wave voltammograms (SWVs), and cyclic voltammograms (CVs) were obtained on commercial paraffin-impregnated graphite bars (Alpino HB type, 2.0 $\mathrm{mm}$ diameter). 
VIMP for reference materials (cuprite and tenorite, both from Merck) was carried out using conventional VIMP protocols by powdering an amount of 1-2 mg of the solid in an agate mortar and pestle, and extending it on the agate mortar forming a spot of finely distributed material. Then the lower end of the graphite electrode was gently rubbed over that spot of sample and finally rinsed with water to remove ill-adhered particles. Sample-modified graphite bars were then dipped into the electrochemical cell so that only the lower end of the electrode was in contact with the electrolyte solution.

Sampling on coins for VIMP measurements was carried out by pressing a graphite bar onto the surface of the coin during $5 \mathrm{~s}$ with different intensity. This procedure ensures that an amount of products forming the corrosion patina of the coin estimated in few nanograms was abrasively transferred to the graphite surface. Then the lower end of the sample-modified graphite electrode was immersed into the electrolyte and the electrochemical runs were performed.

EIS measurements were performed using the tested coin as a working electrode upon partial immersion of the same into the electrolyte. For this purpose, the coins were suspended from an insulating tong and connected to a conventional crocodile clamp as already described [40]. For each piece, experiments were performed for three different immersion depths and varying the position of the clamp but maintaining an immersed area of ca. $1 \mathrm{~cm}^{2}$. Three repeated experiments were performed for each one of these (depth plus clamp position) configurations. Prior to each EIS experiment, an equilibration time of 10 min was taken. EIS measurements were carried out using the aforementioned instrument, in the 0.01 to $100000 \mathrm{~Hz}$ frequency range with amplitude of $10 \mathrm{mV}$ applying a bias potential of $-0.60 \mathrm{~V}$. Air-saturated mineral water from Bejís (Valencian Community, Spain) was used as a electrolyte (Composition: dry residual $159 \mathrm{mg} / \mathrm{L}, \mathrm{HCO}_{3}{ }^{-}: 163 \mathrm{mg} / \mathrm{L}, \mathrm{SO}_{4}{ }^{2-}$ : $\left.16 \mathrm{mg} / \mathrm{L}, \mathrm{Cl}^{-}: \mathrm{mg} / \mathrm{L}, \mathrm{SiO}_{2}: 4.3 \mathrm{mg} / \mathrm{L}, \mathrm{Ca}^{2+}: 47 \mathrm{mg} / \mathrm{L}, \mathrm{Mg}^{2+}: 6.2 \mathrm{mg} / \mathrm{L}, \mathrm{Na}^{+}: 2.8 \mathrm{mg} / \mathrm{L}\right)$.

\subsection{FIB-FESEM-EDX experiments}

Sectioning of trenchs and imaging of the coins in the trench were performed with a FIB-FESEM Zeiss (Orsay Physics Kleindiek Oxford Instruments) model Auriga 
compact equipment that enabled the characterization of the microtexture and mineral phases in the superficial corrosion layer and in the metal core of the ten cash copper coins. The operating conditions were: voltage, $30 \mathrm{kV}$ and current intensity, $500 \mu \mathrm{A}$ and $20 \mathrm{nA}$ in the FIB for generating the focused beam of Ga ions and a voltage of $3 \mathrm{kV}$ in the FESEM for photographs. X-ray linescans were performed in the trench operating with an Oxford-X Max X-ray microanalysis system coupled to the FESEM controlled by Aztec software. A voltage of $20 \mathrm{kV}$ and a working distance of $6-7 \mathrm{~mm}$ was used.

\section{Results and Discussion}

\subsection{Voltammetric pattern}

Figure 1 shows square wave voltammograms recorded for Honan \#01 coin attached to graphite bar in contact with air-saturated aqueous acetate buffer at $\mathrm{pH}$ 4.50. Upon scanning the potential in the negative direction (Fig. 1a), a main cathode peak appears at ca. $-0.10 \mathrm{~V}\left(\mathrm{C}_{1}\right)$ which can be assigned to the reduction of cuprite $\left(\mathrm{Cu}_{2} \mathrm{O}\right)$ and several accompanying copper corrosion products such as malachite or atacamite [22-25]. In agreement with literature and previous reports [22-25,30,31-33], the above signal is accompanied by an ill-defined wave at ca. $-0.35 \mathrm{~V}\left(\mathrm{C}_{2}\right)$ which can be assigned to the reduction of tenorite $(\mathrm{CuO})$ followed by cathodic signals around $-0.70 \mathrm{~V}$ mainly attributable to the reduction of dissolved oxygen often superimposed to reductive processes of traces of lead, tin and zinc corrosion products. Upon scanning the potential in the positive direction (Fig. 1b), an anodic peak at $0.0 \mathrm{~V}\left(\mathrm{~A}_{1}\right)$ was recorded, corresponding to the oxidative dissolution of the deposit of $\mathrm{Cu}$ formed on the graphite surface as a result of the reduction of cuprite, tenorite, etc.

Figure 1 depicts three independent voltammograms for different sample-modified graphite electrodes (black, red and green lines). One can see that, although the peak profile was similar, the peak currents and the ratio between the signals $C_{1}$ and $C_{2}$ vary from one experiment to another. This feature can be attributed to the presence of a different amount of sample abrasively transferred from the coin's patina to the graphite electrode. 
Figure 2 depicts the variation of the peak current ratio (measured from the base line depicted in Figure 1a) of the signals for the reduction of tenorite and cuprite, $i\left(\mathrm{C}_{2}\right) / i\left(\mathrm{C}_{1}\right)$ with the intensity of the first peak, for Tai Ching Ti Kuo \#01 to \#10 and Hupeh \#01 to \#05 coins. One can see that the data points for each series, in spite of relatively high dispersion, fall consistently in a common curve which can be satisfactorily fitted in terms of the regression coefficient to a potential law.

Interestingly, experimental data for Chinese coins were separated from data of more ancient bronze coins, as can be seen in Figure 2, where data for a series of five coins minted in Madrid in 1661 were also plotted. Remarkably, data for these last coins corresponded to $i\left(\mathrm{C}_{2}\right) / i\left(\mathrm{C}_{1}\right)$ values clearly larger than those for Chinese coins minted ca. 1900 , in agreement with the expected increase of the tenorite to cuprite ratio on increasing the age of the objects (providing that comparable base metal and corrosion conditions operated) [30].

\subsection{Modeling in depth distribution of corrosion products}

To rationalize these features, it is pertinent to indicate that, under ordinary corrosion taking place in an atmospheric environment, corrosion of copper/bronze coins proceeds via formation of a primary patina of cuprite subsequently growing and forming a more permeable secondary patina, as described by Robbiola et al. [11-13]. Our data suggest (vide infra) that this secondary patina is progressively enriched in tenorite, whose formation from cuprite in contact with a $\mathrm{O}_{2}$-rich atmosphere is thermodynamically spontaneous $[44,45]$.

Then, and consistently with FIB-FESEM-EDX experiments (vide infra) and studies on bronze patinas [46] and artificial copper oxide thin films [47], one can assume that in the studied coins there is a thin primary patina of cuprite covered by a thick, porous secondary patina mainly constituted by a mixture of cuprite and tenorite microcrystals whose composition varies with the depth $z$. During the sampling process, the graphite electrode was pressed onto the coin patina so that the net volume of metal oxide particles of the secondary patina transferred to the electrode surface, $V$, will vary with the depth reaching in that process as $\mathrm{d} V=S \mathrm{~d} z$. (see scheme presented as a 
Supplementary information, Figure S.5). Since in different sampling steps on the same coin different deep was attained by the graphite bar, the resulting microparticulate deposits whose voltammetric response was recorded were representative of the composition of more or less deep regions of the secondary patina of the coin. Thus, one can expect that the upper corrosion layers are enriched in tenorite relative to the deep ones. Accordingly, there is a concentration gradient of tenorite in the corrosion layers so that the tenorite/cuprite ratio will be larger when sampling is carried out in the external region than when sampling is performed in deeper layers. Although layer-by-layer voltammetric measurements were in principle possible, via controlled abrasion or electrochemical erosion [48] of the corrosion layers, only the described 'smooth' sampling was used in order to minimize the intervention over the coins, as demanded by conservators and restorers.

Now, let us assume that the number of tenorite grains per volume unit, $n_{\text {ten }}$, decreases following a potential law with the depth while the number of cuprite grains per volume unit, $n_{\text {cup }}$, increases so that the total number of copper oxide particles per volume unit, $n$, remains constant. Then, $n_{\text {ten }}=n_{\text {ten }}^{\text {sup }} z^{\alpha} ; n_{\text {cup }}=n_{\text {cup }}^{\text {sup }}+n_{\text {ten }}^{\text {sup }}\left(1-z^{\alpha}\right)$, where $n_{\text {cup }}^{\text {sup }}, n_{\text {ten }}^{\text {sup }}$, represent the surface number of cuprite and tenorite grains, respectively. Under fixed electrochemical conditions, the currents measured for the voltammetric peaks of cuprite and tenorite reduction, $i\left(\mathrm{C}_{1}\right), i\left(\mathrm{C}_{2}\right)$, should be proportional to the total number of cuprite and tenorite grains extracted from the corrosion layers during the sampling process. Accordingly,

$$
\begin{aligned}
& i\left(\mathrm{C}_{2}\right)=\int_{0}^{z} \varepsilon_{\text {ten }} n_{\mathrm{ten}}^{\text {sup }} S z^{\alpha} d z \\
& i\left(\mathrm{C}_{1}\right)=\int_{0}^{z} \varepsilon_{\text {cup }} S\left[n_{\text {cup }}^{\text {sup }}+n_{\mathrm{ten}}^{\text {sup }}\left(1-z^{\alpha}\right) d z\right.
\end{aligned}
$$

Here, $\varepsilon_{\text {cup }}, \varepsilon_{\text {ten }}$, represent electrochemical constants characterizing the respective reduction processes of cuprite and tenorite, only depending on the electrochemical conditions (electrolyte, temperature, potential scan rate, etc.). When $\alpha$ was close to -1 , 
integration of the above equations yields:

$$
\frac{i_{\text {ten }}}{i_{\text {cup }}}=\frac{i\left(\mathrm{C}_{2}\right)}{i\left(\mathrm{C}_{1}\right)}=\frac{\varepsilon_{\text {ten }} n_{\text {ten }}^{\text {sup }}}{\varepsilon_{\text {cup }}}\left(\frac{z^{1+\alpha}}{(1+\alpha) n z+n_{\text {ten }}^{\text {sup }} z^{1+\alpha}}\right)
$$

where $\mathrm{n}=n_{\mathrm{cup}}^{\text {sup }}+n_{\mathrm{ten}}^{\text {sup }}$. Assuming that $(1+\alpha) n z \gg n_{\mathrm{ten}}^{\text {sup }} z^{1+\alpha}$ and approximating $\mathrm{z}=$ $\left.i(\mathrm{C} 1) / \varepsilon_{\text {cup }} S n\right)$ yields:

$$
\frac{i\left(\mathrm{C}_{2}\right)}{i\left(\mathrm{C}_{1}\right)} \approx \frac{\varepsilon_{\text {ten }} n_{\text {ten }}^{\text {sup }}}{(1+\alpha) \varepsilon_{\text {cup }}^{1+\alpha} n^{1+\alpha} S^{\alpha}} i\left(\mathrm{C}_{1}\right)^{\alpha}=A\left(C_{1}\right)^{\alpha}
$$

This equation predicts a potential relationship between the $i\left(\mathrm{C}_{2}\right) / i\left(\mathrm{C}_{1}\right)$ ratio and $i\left(\mathrm{C}_{1}\right)$ which can be experimentally tested. Conceivably, the parameters $n_{\text {ten }}^{\text {sup }}, n_{\text {cup }}^{\text {sup }}, \alpha, \varepsilon_{\text {ten }}, \varepsilon_{\text {cup }}$ and $S$ will be the same for each series of coins, although they can vary from one mint to another.

Consistently, plots of $\log \left[i\left(\mathrm{C}_{2}\right) / i\left(\mathrm{C}_{1}\right)\right]$ vs. $\log \left[i\left(\mathrm{C}_{1}\right)\right]$ provided straight lines of different slopes (see Table 2) but tending to a common ordinate at the origin as can be seen in Figure 3. One can see in this figure how the set of the studied ten-cash Dragon copper coins can be grouped in four electrochemical types labeled as type I (Tai Ching Ti Kuo \#01 to \#10) and Tsingkiang, type II (Anhwei and Hupeh), type III (Hu Poo, Peiyang, Honan, Kiangsi and Kiangnan) and type IV (Kwangtung, and Hunan). Interestingly, the data point for coin Tai Ching Ti Kuo \#11 falls in the region of type II coins.

\subsection{Electron microscopy analysis}

In order to explore the reasons for the above mint-characteristic differences in the electrochemical response of coins, FIB-FESEM-EDX experiments using a Ga ions microbeam were performed. This technique can be considered as micro-invasive as the ionic microbeam yields trenches which size is lower than $10 \mu \mathrm{m}$ not detectable at the macroscopic level. Figure 4 shows the secondary electron images of trench $c a .10 \mu \mathrm{m}$ length and $c a .15 \mu \mathrm{m}$ depth generated by FIB in the region of interest in the coins $\mathrm{Hu}$ 
Poo \#02 and Tai Ching Ti Kuo \#09. In both cases, the obtained trench extends from the outer corrosion layers down to the metal core of the coin. Remarkably, not only the texture of the corrosion layer in the upper region of the trench, but also the grained microtexture of the metal core of the coins appears as different. The metal core exhibits abundant facets of columnar habit overlapped with larger domains in the case of $\mathrm{Hu}$ Poo coins whereas the section of the Tai Ching Ti Kuo coins shows a network of large angular domains.

Additionally, coupling EDX analysis to FIB-FESEM imaging permits to determine the composition of the core metal and the layer by layer composition of the corroded region Figure 5 depicts the variation of the $\mathrm{Cu}$ content with the depth $(z)$ determined from FESEM-EDX data for coins representative of each one of the aforementioned electrochemical types. There are differences in the concentration gradient in the external $(0<z<3 \mu \mathrm{m})$ region of the trenches which, in principle, would be illustrative of the existence of different corrosion patterns, but these were mainly attributable to the different corrosion history of individual coins. The most clear regularity, however, was observed in the copper content in the metal core (see inset in Figure 5). Averaged values from measurements in three different coins of each one of the electrochemical types I-IV suggested an increase of the $\mathrm{Cu}$ content from series I to IV.

In order to test the above modeling with FIB-FESEM-EDX data, the depth variation of the 'absolute' concentration of copper was probably the most robust parameter. Let us assume that the decrease of $\mathrm{Cu}$ concentration is due exclusively to the formation of cuprite and tenorite. This is an obvious oversimplification especially when strong corrosion exists so that a tertiary patina is formed. However, for smooth corrosion, the number of copper crystals per volume unit in the secondary patina, $n_{\mathrm{Cu}}$, existing at a depth $z$ should satisfy the relationship:

$$
n_{\mathrm{Cu}}=n_{\mathrm{Cu}}^{\mathrm{o}}-n_{\mathrm{ten}}-2 n_{\mathrm{cup}}=n_{\mathrm{Cu}}^{\mathrm{o}}-n_{\mathrm{ten}}^{\mathrm{sup}}(\delta-z)^{\alpha}-n_{\mathrm{cup}}^{\mathrm{o}}+2 n_{\mathrm{ten}}^{\mathrm{sup}}(\delta-z)^{\alpha}
$$

where $n_{C u}^{o}$ denotes the copper concentration at the base metal. Accordingly, the 
variation of the ratio between the copper concentration at a depth $z$ and the maximum copper concentration will be:

$$
\frac{n_{\mathrm{Cu}}}{n_{\mathrm{Cu}}^{\mathrm{o}}}=\frac{n_{\mathrm{Cu}}^{\mathrm{o}}-n_{\mathrm{cup}}^{\mathrm{o}}+n_{\mathrm{ten}}^{\mathrm{sup}}(\delta-z)^{\alpha}}{n_{\mathrm{Cu}}^{\mathrm{o}}}=1-\frac{n_{\mathrm{cup}}^{\mathrm{o}}}{n_{\mathrm{Cu}}^{\mathrm{o}}}+\frac{n_{\mathrm{ten}}^{\mathrm{sup}}}{n_{\mathrm{Cu}}^{\mathrm{o}}}(\delta-z)^{\alpha}
$$

which corresponds to a potential increase with depth. Experimental FIB-FESEM data agreed (see Figure 6) with this theoretical model. Accordingly, one can assume that the differences observed in the voltammetric response are attributable to the different corrosion pattern resulting, presumably, from the different chemical composition and, mainly, microcyrstalline structure of the base metal, in turn resulting from possible differences in the raw material, dosification and, mainly, the thermomechanical process used in the fabrication of the coins.

\subsection{Impedance analysis}

In order to corroborate the above ideas, EIS experiments were performed using air-saturated mineral water as a non-aggressive electrolyte [39] and the reduction of dissolved oxygen which acts as a redox probe [40-42]. Figure 7 compares the experimental data for coins of the types I and IV. The Nyquist plots consist of a depleted capacitive loop slightly distorted at high frequencies whereas the Bode plots present two maxima in the phase angle at high and intermediate frequencies. These spectra can be described in terms of equivalent circuits analogue to those previously reported [40-42] comprising two parallel combinations of resistance and constant phase elements roughly representative of charge transfer and charge separation through/in the electrolyte/corrosion layer and corrosion layer/metal core interfaces.

As can be seen in Figure 7, the obtained impedance spectra varied in successive measurements on the same coin (black, red and green data points), presumably as a result of surface hydration/equilibration [41]. Accordingly, different sets of values of the impedance parameters were obtained for each coin. Pairs of such parameters, however, were grouped defining tendency lines in the corresponding two-parameter 
representations. For simplicity an empirical correlation between the maximum phase angle at middle frequencies, $\varphi_{\mathrm{m}}$, and the frequency at which this maximum appears, $f_{\mathrm{m}}$ was taken for grouping different coins. Pertinent data can be seen in Figure 8, where one can see that coins of the previous VIMP groups I, II and III fall around lightly separated tendency lines in the $-\varphi_{\mathrm{m}} \mathrm{vs} . \log \left(f_{\mathrm{m}}\right)$ diagram. The coins of the group IV, were apparently divided into those from Kwangtung, which are close to groups I-III and those from Hunan. As observed in the case of VIMP grouping, the coin Tai Ching Ti Kuo \#11 was close to the coins of types II and III. For our purposes, the relevant point to emphasize is that an essentially consistent electrochemical grouping was obtained from two independent techniques.

\subsection{Archaeometric implications}

The obtained electrochemical grouping can be correlated with geographical and temporal data (see Supplementary information, Fig. S.6) and can be summarized as:

a) Type I was used in the Tsingkiang mint and was coincident to the Tai Ching Ti Kuo unified production. The latter was divided into the Board of Revenue (Hu Poo) and different provincial sub-series (Hupeh, Hunan, Anwhei, Kiangnan and Ssûch'uan (Szechwan)), one of which (Kiangnan) corresponded to the type III, (see Supplementary information, Fig. S.7) thus suggesting that the presumed unification was only partial.

b) Type II was minted in the central provinces of Hupeh and Anhwei.

c) Type III was minted in the central provinces of Honan, Kiangnan and Kiangsi and was coincident with the unified series labeled here as Hu Poo and Peiyang mint.

d) Type IV was produced in the southern provinces of Hunan and Kwantung. Since the modern monetary production started in Kwantung in 1889, this type can be considered as the precedent of all other series.

Accordingly, electrochemical data confirm the idea that independent-like provincial mints operated before the monetary unification. Experimental data for coins of the Tai Ching Ti Kuo series, where several mints were used, are provided as a Supplementary material, Fig. S6. Although possibly with light variations between them, coins with no 
mint indication and those from Hupeh, Ssûch'uan (Szechwan) and Kwantung mints fall in a common potential line in the $i\left(\mathrm{C}_{2}\right) / i\left(\mathrm{C}_{1}\right)$ vs. $i\left(\mathrm{C}_{1}\right)$ diagram. However, Tai Ching Ti Kuo coins from Kiangnan deviate clearly from the above tendency and fall in the line corresponding to the production of regular provinces of type III (Honan, Kiangnan and Kiangsi, see also Fig. 3).

Such data indicate that, contrary to the idea that a complete renewal of the monetary production accompanied the unification, the initial production of unified currency $(\mathrm{Hu}$ Poo series), followed the production pattern of the central provinces Honan, Kiangnan and Kiangsi (type III). This mode would be changed for producing the unified series (Tai Ching Ti Kuo, type I). Our results clearly suggest that the unified mode of production was changed between 1905 and 1906. In fact, the experimental data points for one of the Tai Ching Ti Kuo coins (\#11) were clearly separated from the type I in the diagrams depicted in Figures 2, 3 and 8. A reasonable hypothesis is that the Tai Ching Ti Kuo was initiated following one of the previous provincial modes but that the production was early modified. In fact, the coins of the Tai Ching Ti Kuo series, contrary to the presumed unification, were prepared in several mints and at least one of which (Kiangnan, see Figures 3 and S6) was fabricated following precedent procedures. These data are indicative that the imperial monetary unification was stepwise and partial.

An additional aspect to underline is that data in Figs. 2 and 3, denoting that the tenorite/cuprite ratio is sensitive to the depth of sampling and the composition and thermomechanical mode of preparation of the metal, are also of interest in regard to the previously described electrochemical dating of copper/bronze objects $[30,42]$. Such data suggest that the $\alpha$-exponent in Eq. (3) is quite sensitive to the composition and thermomechanical treatment of the alloy whereas the $A$-coefficient, which is representative of the tenorite/cuprite ratio at the more external region of the corrosion layer, would be representative of the corrosion time (under uniform and common conditions of aging) and much less sensitive to the thermomechanical mode of preparation. A-values for the Spanish maravedis $(6.39 \pm 0.04)$, the four series of Chinese 
coins studied here (averaged value, $2.90 \pm 0.15$ ), and eurocent coins $(2.08 \pm 0.11$ ), are in agreement with this idea. Accordingly, A-data can provide a refined age estimate relative to that based on an averaged estimate of that ratio [30] but further series of data have to be considered for this purpose.

\section{Conclusions}

Using minimally invasive sampling, the voltammetry of microparticles methodology yields well-defined voltammetric responses for nanosamples of the patina of coins displaying characteristic features of cuprite and tenorite. The depth variation of the relative intensity of tenorite and cuprite signals can be modeled using a potential law which is in agreement with experimental voltammetric data and EDX analysis and is also consistent with data from EIS. Application of such techniques to a series of 10 cash copper coins produced around the Kuang Hsu (光绪) Chinese emperor last monetary unification provided the discrimination of different mints based on characteristic voltammetric and impedance features. The differences in the voltammetric response can be associated, in agreement with FIB-FESEM-EDX examination of coins, to subtle mint-characteristic differences in the composition and thermomechanical processing of the base alloy. Accordingly, characteristic depth-depending electrochemical data are usable for discrimination of monetary series and refining electrochemical dating of copper/bronze objects, thus providing a complementary tool for numismatic and archaeological studies.

Acknowledgements. Financial support from the Spanish MINECO Projects CTQ2014-53736-C3-1-P and CTQ2014-53736-C3-2-P which are also supported with ERDF funds. The Universita degli Studi di roma "La Sapienza" has granted a six-months research-scholarship to the graduated Elena Montagna. The authors also wish to thank Dr. José Luis Moya López and Mr. Manuel Planes Insausti (Microscopy Service of the Universitat Politècnica de València) for technical support. 


\section{References}

[1] D. Attanasio, G. Bultrini, G.M Ingo, Archaeometry, 43 (2001) 529-547.

[2] J.V. Gimeno-Adelantado, M.A. Ferrer-Eres, F.M. Valle-Algarra, J. Peris-Vicente, F. Bosch-Reig. Talanta 60 (2003) 895-910.

[3] S. Shalev, S. Sh. Shilstein, Yu Yekutieli, Talanta 70 (2006) 909-913.

[4] R. Gaudiuso, M. Dell'Aglio, O. De Pascale, S. Loperfido, A. Mangone, A. Anal. Chim. Acta 813 (2014) 15-24.

[5] S. Guirado, F.J. Fortes, J.J. Laserna, Talanta 137 (2015) 182-188.

[6] A. Duran, L.K. Herrera, M.C. Jimenez de Haro, A. Justo, J.L. Perez-Rodriguez, Talanta 76 (2008) 183-188.

[7] P. Budd, D. Gale, A.M. Pollard, R.G. Thomas, P.A. Williams, Archaeometry 35 (1993) 241-247.

[8] E. Ribechini, F. Modugno, C. Baraldi, P. Baraldi, M.P. Colombini, Talanta 74 (2008) $555-561$.

[9] M. Tomassetti, F. Marini, R. Bucci, L. Campanella, Trends in Analytical Chemistry, 79 (2016) 371-379.

[10] D.A. Scott, Journal of the American Institute of Conservation 33 (1994) 1-23.

[11] L. Robbiola, J.M. Blengino, C. Fiaud, Corros. Sci. 40 (1998) 2083-2111.

[12] L. Robbiola, R. Portier, J. Cult. Herit. 7 (2006) 1-12.

[13] C. Chiavari, K. Rahmouni, H. Takenouti, S. Joiret, P. Vermaut L. Robbiola, Electrochim. Acta 52 (2007) 7760-7769.

[14] I. Constantinides, A. Adriaens, F. Adams, Appl. Surf. Sci. 189 (2002) 90-101.

[15] I. De Ryck, A. Adriaens, E. Pantos, F. Adams, Analyst 128 (2003) 1104-119.

[16] M.C. Bernard, S. Joiret, Electrochim. Acta 54 (2009) 5199-5205.

[17] F. Scholz, B. Meyer, Voltammetry of solid microparticles immobilized on electrode surfaces. Electroanalytical Chemistry, A Series of Advances. Bard, A. J., and Rubinstein, I., Eds., Marcel Dekker, New York 20 (1998) 1-86.

[18] F. Scholz, U. Schröder, R. Gulaboski, A. Doménech-Carbó, Electrochemistry of Immobilized Particles and Droplets. $2^{\text {nd }}$ Edit. Springer, Berlin-Heidelberg (2014). 
[19] A. Doménech-Carbó, J. Labuda, F. Scholz, Pure Appl. Chem. 85 (2013) 609-631 (IUPAC Technical Report).

[20] Y. Niu, F. Sun, Y. Xu, Z. Cong, E. Wang. Talanta 127 (2014) 211-218.

[21] A. Doménech-Carbó, M. T. Doménech-Carbó, V. Costa, Electrochemical Methods in Archaeometry, Conservation and Restoration. Monographs in Electrochemistry Series, Scholz, F., Ed. Springer, Berlin-Heidelberg (2009).

[22] M. Serghini-Idrissi, M.C. Bernard, F.Z. Harrif, S. Joiret, K. Rahmouni, A. Srhiri, H. Takenouti, V. Vivier, M. Ziani, Electrochim. Acta 50 (2005) 4699-4709.

[23] V. Costa, K. Leyssens, A. Adriaens, N. Richard, F. Scholz, J. Solid State Electrochem. 14 (2010) 449-451.

[24] D. Satovic, S. Martinez, A. Bobrowski, Talanta 81 (2010) 1760-1765.

[25] F.A. Gholenji, A. Adriaens, J. Solid State Electrochem. 16 (2012) 535-543.

[26] D. Blum, W. Leyffer, R. Holze, Electroanalysis 8 (1996) 296-297.

[27] A. Doménech-Carbó, M.T. Doménech-Carbó, M.A. Peiró-Ronda, Electroanalysis 23 (2011) 1391-1400.

[28] A. Doménech-Carbó, M.T. Doménech-Carbó, M.T., Peiró-Ronda, M.A., L. Osete-Cortina, Archaeometry 53 (2011) 1193-1211.

[29] A. Doménech-Carbó, M.T. Doménech-Carbó, M.A. Peiró-Ronda, Anal. Chem. 83 (2011) 5639-5644.

[30] A. Doménech-Carbó, M.T. Doménech-Carbó, S. Capelo, T. Pasíes, I. Martínez-Lázaro, Angew. Chem. Int. Ed. 53 (2014) 9262-9266.

[31] A. Doménech-Carbó, M.T. Doménech-Carbó, T. Pasíes, M.C. Bouzas. Electroanalysis 24 (2012) 1945-1955.

[32] A. Doménech-Carbó, J. Del Hoyo-Menéndez, M.T. Doménech-Carbó, J. Piquero-Cilla, Microchem. J. 130 (2017) 47-55.

[33] F. Di Turo, N. Montoya, J. Piquero-Cilla, C. De Vito, F. Coletti, G. Favero, A. Doménech-Carbó, Anal. Chim. Acta 955 (2017) 36-47.

[34] D.D. Macdonald, Electrochim. Acta 56 (2011)1761-1772.

[35] N. Souissi, L. Bousselmi, S. Khosrof, E. Triki, Mater. Corros. 55 (2004) 284-292. 
[36] N. Souissi, E. Triki, Mater. Corros. 60 (2009) 262-268.

[37] A.L. Mata, M.M.L. Salta, M.M.M. Neto, M.H. Mendonça, I.T.E. Fonseca, Mater. Corros. 61 (2010) 205-210.

[38] E. Cano, D. Lafuente, D.M. Bastidas, J. Solid State Electrochem. 14 (2010) 381-391.

[39] C. DeGrigny, G. Guibert, S. Ramseyer, G. Rapp, A. Tarchini, J. Solid State Electrochem. 14 (2010) 425-436.

[40] A. Doménech-Carbó, M.T. Doménech-Carbó, M.A. Peiró-Ronda, I. Martínez-Lázaro, J. Barrio, J. Solid State Electrochem. 16 (2012) 2349-2356.

[41] A. Doménech-Carbó, M. Lastras, F. Rodríguez, L. Osete-Cortina, J. Solid State Electrochem. 18 (2014) 399-409.

[42] A. Doménech-Carbó, S. Capelo, J. Piquero-Cilla, M.T. Doménech-Carbó, J. Barrio, A. Fuentes, W. Al-Sekkaneh. Mater. Corros. 67 (2016) 120-129.

[43] A.M. Tracey Woodward, The minted ten-cash coins of China, M.R. Fried Publ. Oakland (1971).

[44] D.A. Scott, Stud. Conservat. 42 (1997) 93-100.

[45] M.T. S. Nair, L. Guerrero, O.L. Arenas, P.K. Nair, Appl. Surf. Sci. 150 (1999) $143-151$.

[46] P. Ropret, T. Kosec, J. Raman Spectrosc. 43 (2012) 1578-1586.

[47] H. Stein, D. Naujoks, D. Grochla, C. Khare, R. Gutwoski, S. Grützke, W. Schuhmann, A. Ludwig, Phys. Status Solidi A 212 (2015) 2798-2804.

[48] A. Doménech-Carbó, M.T. Doménech-Carbó, I. Martínez-Lázaro, Anal. Chim. Acta $680(2010) 1-9$. 
Figures

Figure 1. Square wave voltammograms (black, red and green lines correspond to three independent measurements at freshly sample-modified electrodes) of samples from coin Honan \#01 attached to graphite bar immersed into air-saturated 0.25 M HAc/NaAc aqueous buffer, $\mathrm{pH} 4.50$. Potential scan initiated a) at $+0.75 \mathrm{~V}$ in the negative direction and b) $-0.75 \mathrm{~V}$ in the positive direction. Potential step increment $4 \mathrm{mV}$; square wave amplitude $25 \mathrm{mV}$; frequency $5 \mathrm{~Hz}$. Horizontal dotted lines represent the base lines for peak current measurements. Inset: photographic image of the obverse (left) and reverse (right) coin.

Figure 2. Variation of the $i\left(\mathrm{C}_{2}\right) / i\left(\mathrm{C}_{1}\right)$ ratio on $i\left(\mathrm{C}_{1}\right)$ for Tai Ching Ti Kuo and Hupeh coins and Spanish maravedis minted in Madrid in 1661. Independent measurements for three samples of each coin from voltammograms such as in Figure 1. Continuous lines correspond to the fit of each series of data to a potential law. Bars correspond to estimated uncertainties of $\pm 10 \%$.

Figure 3. Variation of $\log \left[i\left(\mathrm{C}_{2}\right) / i\left(\mathrm{C}_{1}\right)\right]$ on $\log \left[i\left(\mathrm{C}_{1}\right)\right]$ for the 10 cash Dragon copper coins studied here and electrochemical grouping of the different series. Circles correspond to data for the coin Tai Ching Ti Kuo \#11.

Figure 4. Secondary electron images of trench $c a$. $10 \mu \mathrm{m}$ length and $c a .15 \mu \mathrm{m}$ depth generated by FIB in the region of interest in the coins: a,b) Hu Poo \#02 and c,d) Tai Ching Ti Kuo \#09 coins at two different magnifications.

Figure 5. Variation of the $\mathrm{Cu}$ content with the depth $(z)$ determined from FIB-FESEM-EDX data for coins Tai Ching Ti Kuo \#06 (grey rhombs), Anhwei \#01 (grey squares), Hu Poo \#01 (rhombs) and Hunan \#01 (black squares). Inset: interval of copper content values in the metal core from measurements in three different coins of each one of the electrochemical types I-IV. 
Figure 6. Depth variation of the $\% \mathrm{Cu} / \% \mathrm{Cu}(\max )$ ratio determined from FIB-FESEM-EDX data for Hu Poo \#01 (squares) and Hunan \#01 (solid squares) coins. When the primary patina was reached, the proportion of $\mathrm{Cu}$ remained essentially constant. Curved lines correspond to data fitting to a potential law.

Figure 7. EIS of coins a,b) Kwantung \#02 and c,d) Tai Ching Ti Kuo \#06 in contact with air-saturated mineral water. a,c) Bode plots of -(phase angle) vs. $\log ($ frequency) and b,d) Nyquist plots of $-Z_{\text {imag }}$ vs. $Z_{\text {real }}$. Bias potential $-0.60 \mathrm{~V}$. Black, red and green data points correspond to three successive EIS measurements on the same coin.

Figure 8. Variation of $-\varphi_{\mathrm{m}}$ on $\log \left(f_{\mathrm{m}}\right)$ in EIS of the studied coins in conditions such as in Figure 6. Three successive measurements were superimposed for each coin. Continuous lines correspond to the fit of each series of data to a potential law. Circles correspond to data for the coin Tai Ching Ti Kuo \#11. 
Table 1. Summary of historical data on mints in this study.

\begin{tabular}{|c|c|}
\hline Mint & Characteristics [43] \\
\hline \multicolumn{2}{|c|}{ Regular Provincial Series } \\
\hline $\begin{array}{l}\text { Anhwei } \\
\text { (安徽) }\end{array}$ & $\begin{array}{l}\text { The minting plant started producing in } 1723-1735 \text { in the capital Anking. } \\
\text { The mint was dismantled in } 1899 \text { and re-opened in } 1902 .\end{array}$ \\
\hline $\begin{array}{l}\text { Tsingkiang } \\
\text { (Chinkiang) } \\
\text { (清江) }\end{array}$ & $\begin{array}{l}\text { The Chinkiang mint did not represent any particular province. It was a } \\
\text { unit amongst the many modern mints in China that limited its } \\
\text { operations to the production of copper ten-cash pieces. The mint started } \\
\text { operating in the city of Tsin-kiang } \mathrm{Pu} \text { in the province of Kiangsu in } \\
1905 \text { and closed in } 1907 \text {. }\end{array}$ \\
\hline $\begin{array}{l}\text { Honan } \\
\text { (河南) }\end{array}$ & $\begin{array}{l}\text { The K'ai-feng } \mathrm{Fu} \text { mint operated since 1647. Modern mint was } \\
\text { established in } 1901 \text { and closed in } 1914 \text {. }\end{array}$ \\
\hline $\begin{array}{l}\text { Hunan } \\
\text { (湖南) }\end{array}$ & $\begin{array}{l}\text { The modern British facility of the Changsha mint, specially designed } \\
\text { for striking copper coins, began operations in } 1901 .\end{array}$ \\
\hline $\begin{array}{l}\text { Hupeh } \\
\text { (湖北) }\end{array}$ & $\begin{array}{l}\text { Minting in the capital, Wuchang, was initiated in } 1893 \text { by Viceroy } \\
\text { Ch'ang Ch'ih-tung. This mint began to strike copper coins in } 1900 . \\
\text { Copper coinage was suspendend in } 1906 \text { owing to excessive issue. }\end{array}$ \\
\hline $\begin{array}{l}\text { Kiangnan } \\
\text { (江南) }\end{array}$ & $\begin{array}{l}\text { This province was composed of the two current provinces of Anhwei } \\
\text { and Kiangsu. The mint started in } 1897 \text { in Nanking, the capital of } \\
\text { Kiangsu province. Modern mint was established in 1901. }\end{array}$ \\
\hline $\begin{array}{l}\text { Kiangsi } \\
\text { (江西) }\end{array}$ & The modern machinery was introduced in the Nan-chang mint in 1901. \\
\hline $\begin{array}{l}\text { Kwantung } \\
\text { (廣東) }\end{array}$ & $\begin{array}{l}\text { The Canton mint with modern machinery opened in } 1889 \text { by Viceroy } \\
\text { Ch'ang Ch'ih-tung with Edward Wyon as superintendent. The first ten } \\
\text { cash copper coins to appear in China were struck by the Canton mint in } \\
1900\end{array}$ \\
\hline $\begin{array}{l}\text { Peiyang } \\
\text { (北洋) }\end{array}$ & $\begin{array}{l}\text { Peiyang is the name of a mint located at Tientsin in the ancient Chihli } \\
\text { (Hopeh) province. In numismatic treatises [43] the currency exhibiting } \\
\text { the Peiyang (北洋) mintmark and the denomination of Peiyang in } \\
\text { English in the reverse of the coins is presented separately to the coined } \\
\text { currency from the Chihli province. Historically, this establishment } \\
\text { formed a branch of the Arsenal known under that name at Tientsin. } \\
\text { Copper coinage was initiated in } 1896 \text { by Li Hung-chang. The mint was } \\
\text { destroyed during the Boxer Rebellion in 1900. Modern machinery was } \\
\text { subsequently installed and coining of currency was initiated from } 1902 \\
\text { until } 1908 \text { when the establishment was closed. }\end{array}$ \\
\hline \multicolumn{2}{|c|}{ Hu Poo and Tai Ching Ti Kuo series } \\
\hline $\begin{array}{l}\mathrm{Hu} \mathrm{Poo} \\
\text { (戶部) }\end{array}$ & $\begin{array}{l}\text { Coins bearing the inscription Hu Poo (Board of Revenue) (戶部) do not } \\
\text { denote any particular province. Struck ten-cash coins of this series were } \\
\text { mint at Tientsin by the Peiyang mint under the auspices of the Board of } \\
\text { Revenue that functioned in the same manner as a central mint }\end{array}$ \\
\hline $\begin{array}{l}\text { Tai Ching } \mathrm{Ti} \\
\text { Kuo }\end{array}$ & $\begin{array}{l}\text { This series of ten-cash coins were produced in several mints situated } \\
\text { widely apart under the authority of the Hu Poo (戶部) and, after 1906, } \\
\text { the Tu Chih Poo (度支部). Some of them bear the provincial } \\
\text { countermark in the middle of the obverse whereas others do not bear } \\
\text { any particular province countermark }\end{array}$ \\
\hline
\end{tabular}



Table 2. Statistical parameter for linear regression of $\log \left[i\left(\mathrm{C}_{2}\right) / i\left(\mathrm{C}_{1}\right)\right]$ vs. $\log \left[i\left(\mathrm{C}_{1}\right)\right]$ plots for different series of coins.

\begin{tabular}{|l|l|l|l|l|}
\hline Series & $N$ & Slope & Ordinate at the origin & $\boldsymbol{r}$ \\
\hline Chinese coins, type I & 28 & $-0.70 \pm 0.03$ & $0.48 \pm 0.03$ & 0.968 \\
\hline Chinese coins, type II & 24 & $-0.78 \pm 0.04$ & $0.44 \pm 0.03$ & 0.975 \\
\hline Chinese coins, type III & 32 & $-1.03 \pm 0.04$ & $0.45 \pm 0.03$ & 0.967 \\
\hline Chinese coins, type IV & 18 & $-1.59 \pm 0.07$ & $0.49 \pm 0.04$ & 0.985 \\
\hline Maravedis Spanish coins, 1661 & 10 & $-0.58 \pm 0.04$ & $0.55 \pm 0.04$ & 0.984 \\
\hline
\end{tabular}


Figure 1.

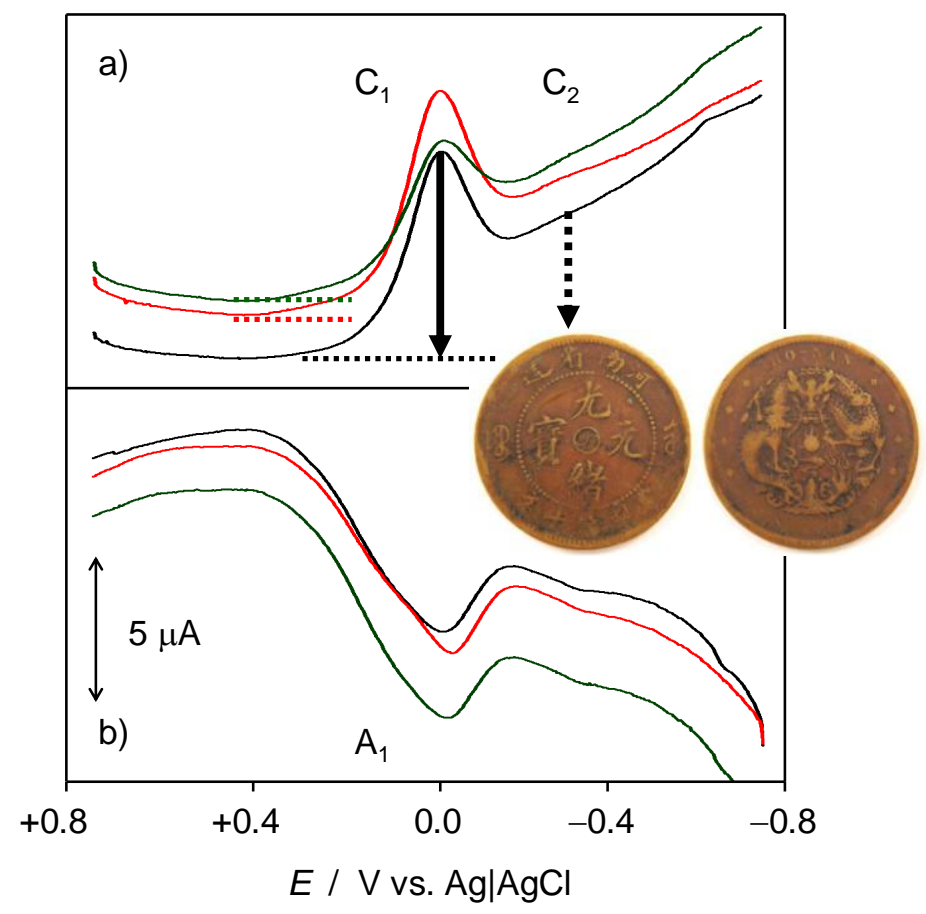


Figure 2.

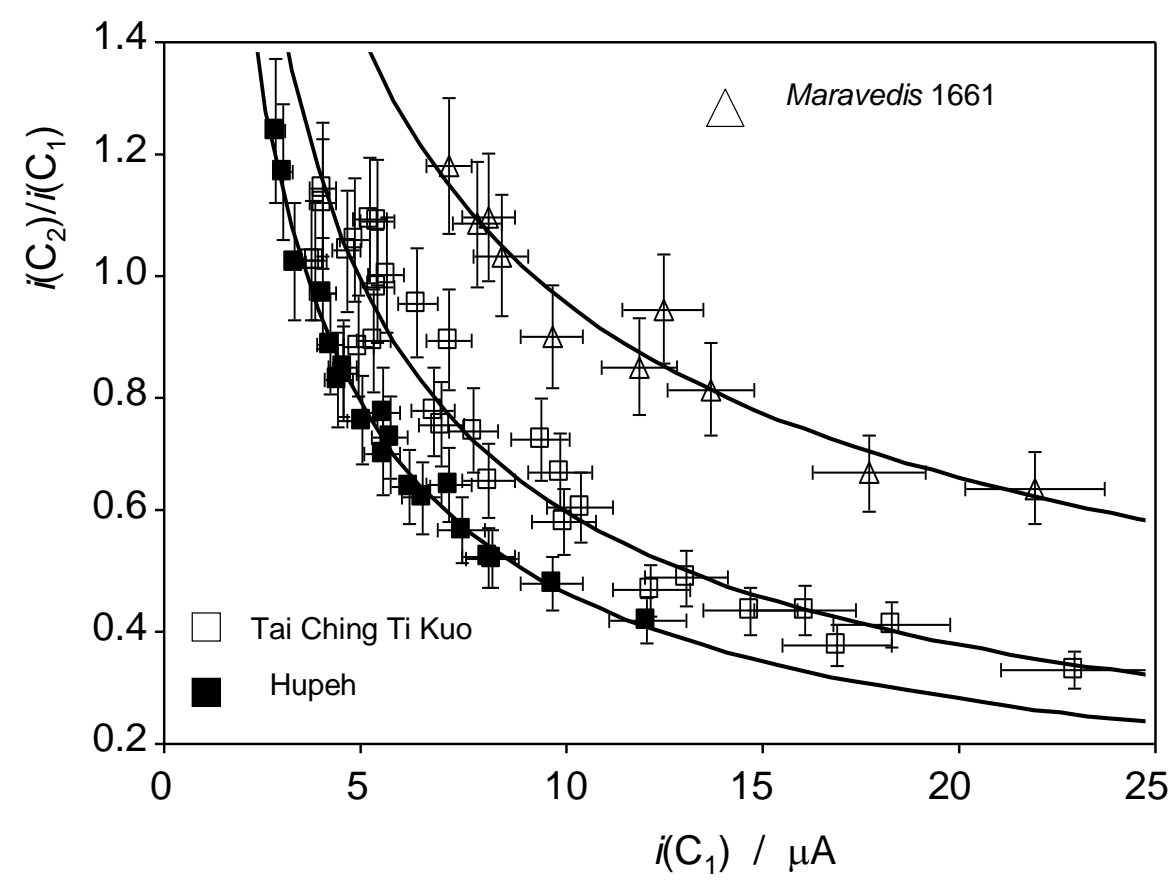


Figure 3.

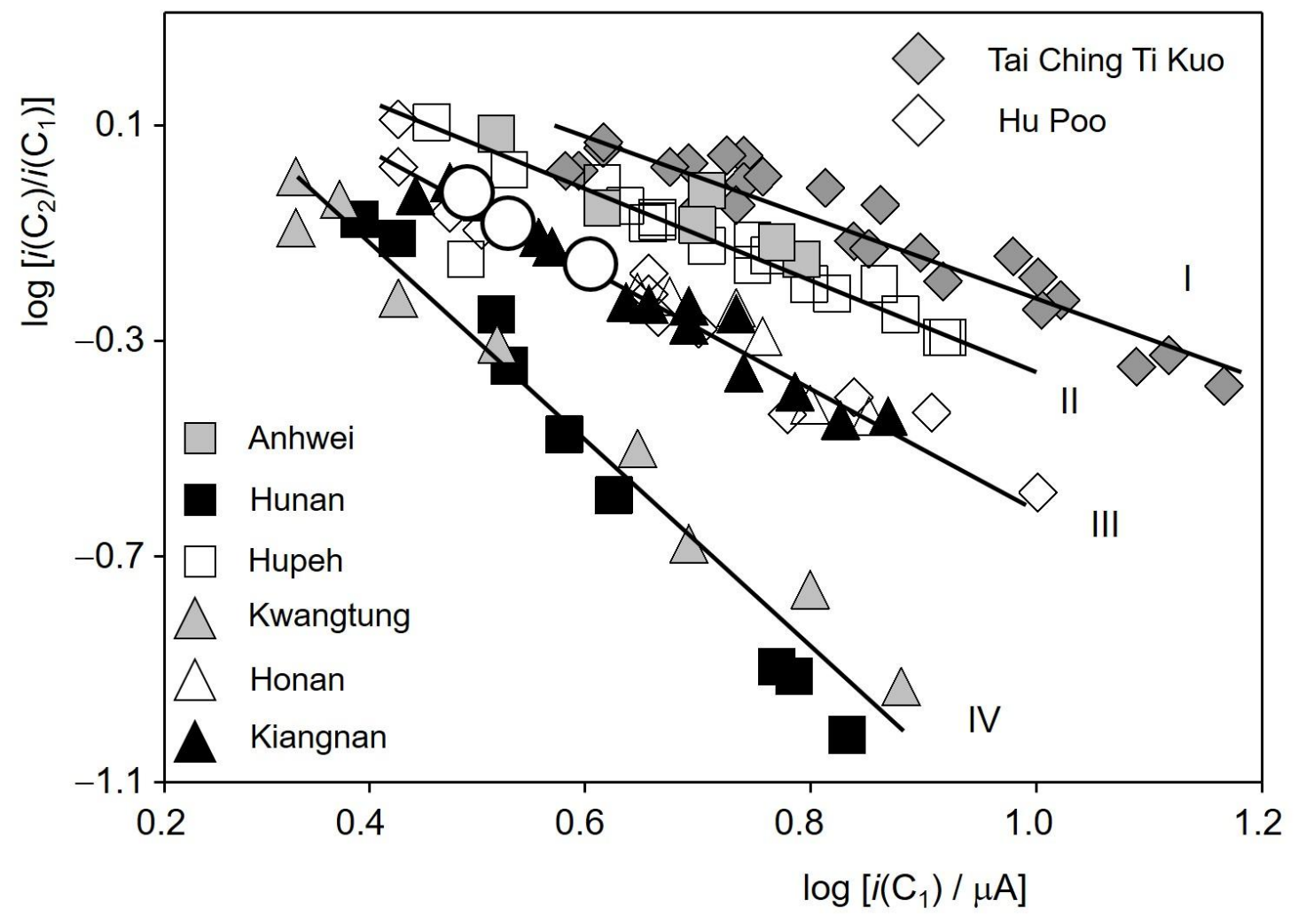


Figure 4.
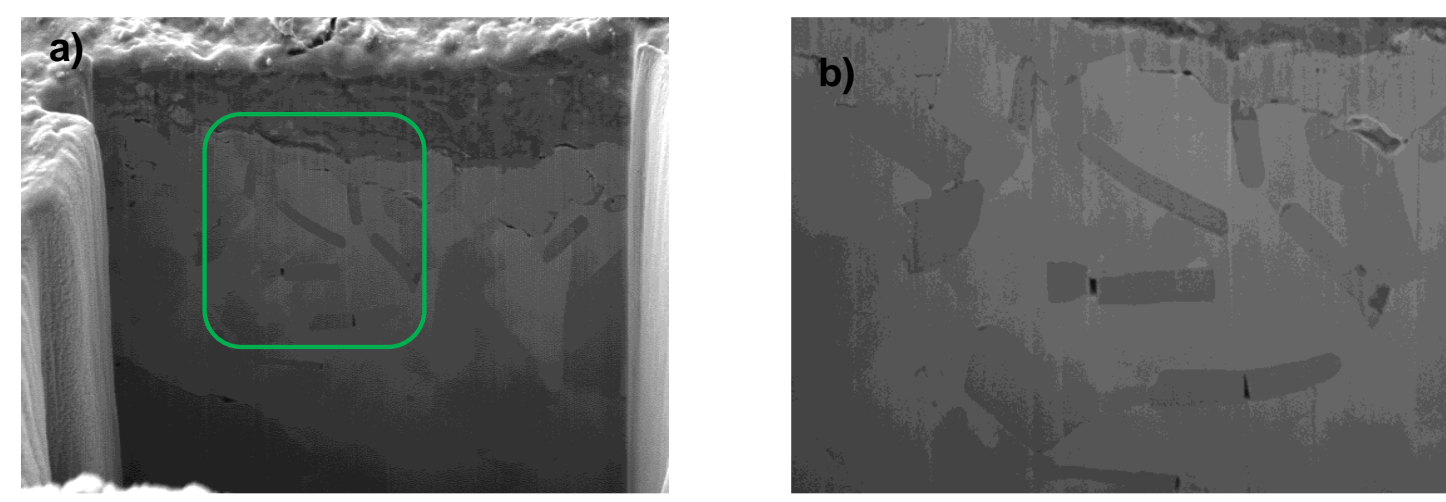

$\longleftrightarrow \quad 1 \mu \mathrm{m}$
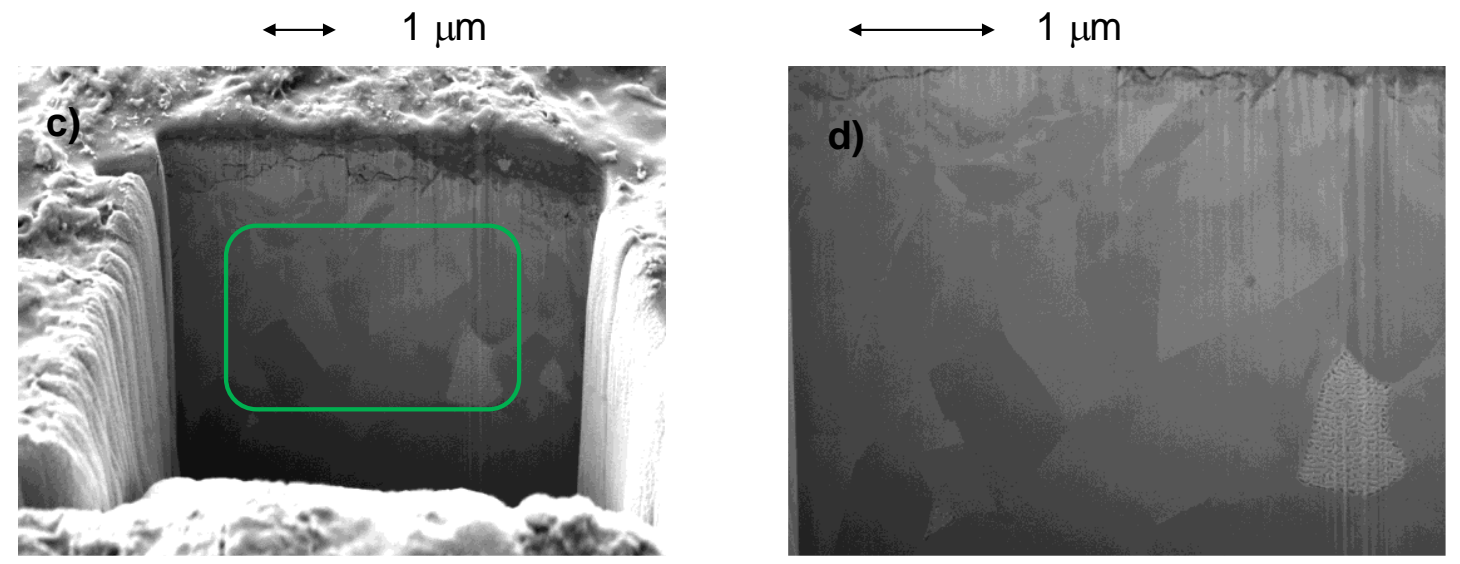
Figure 5.

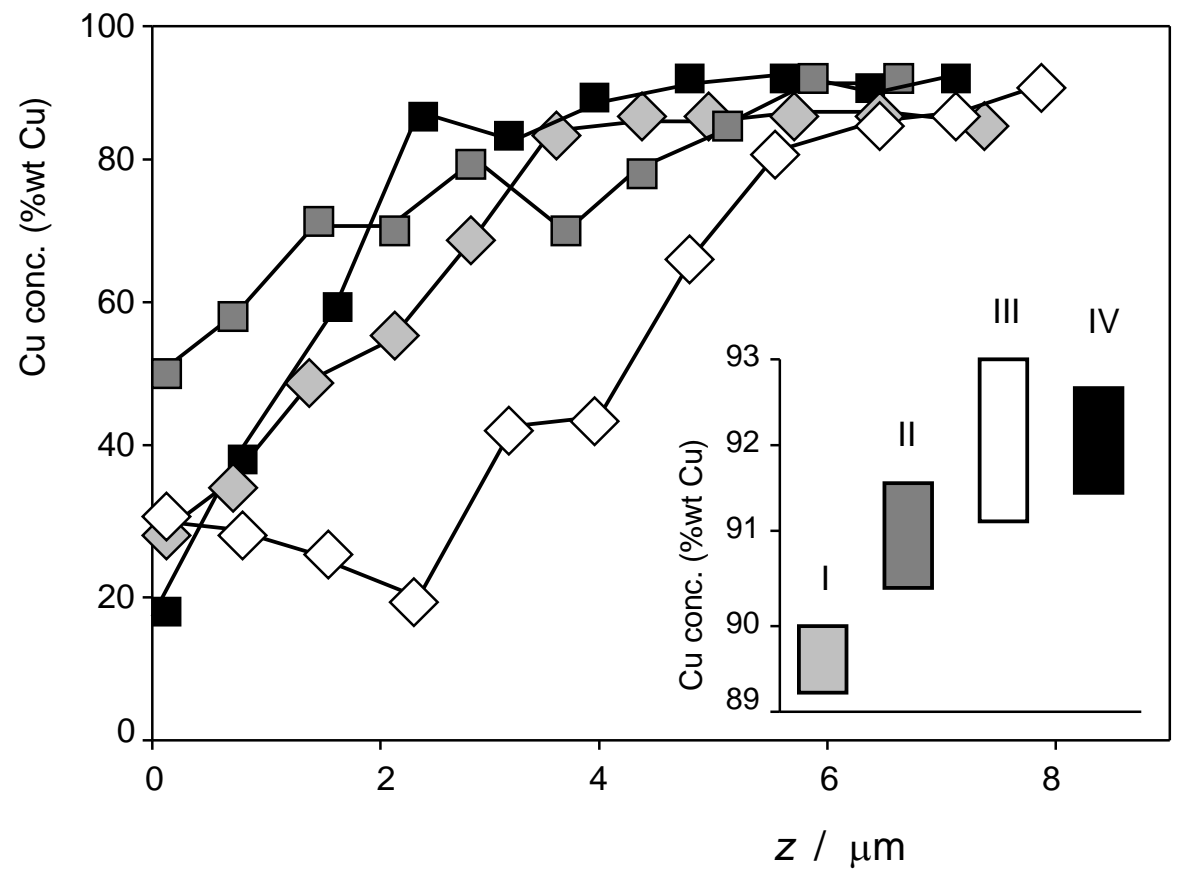


Figure 6.

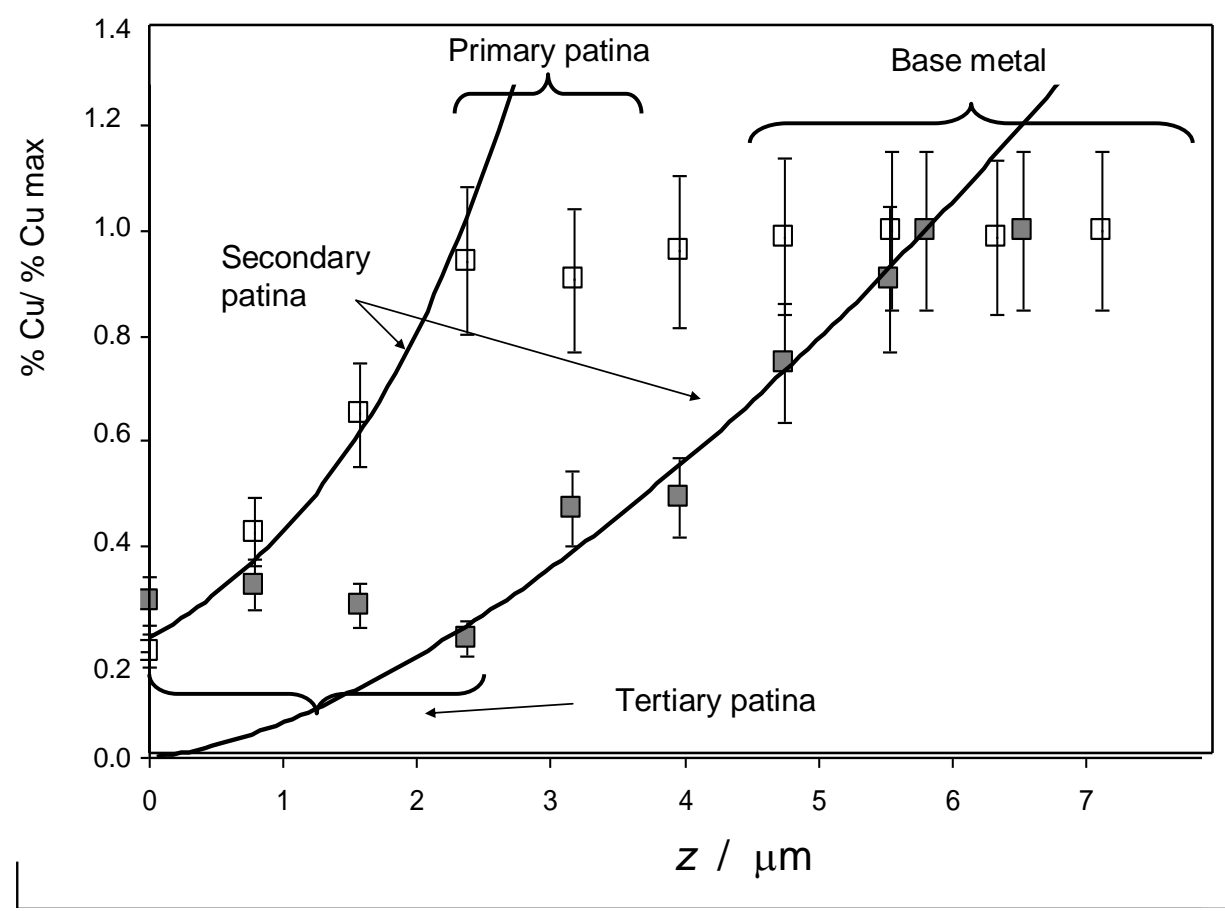


Figure 7.

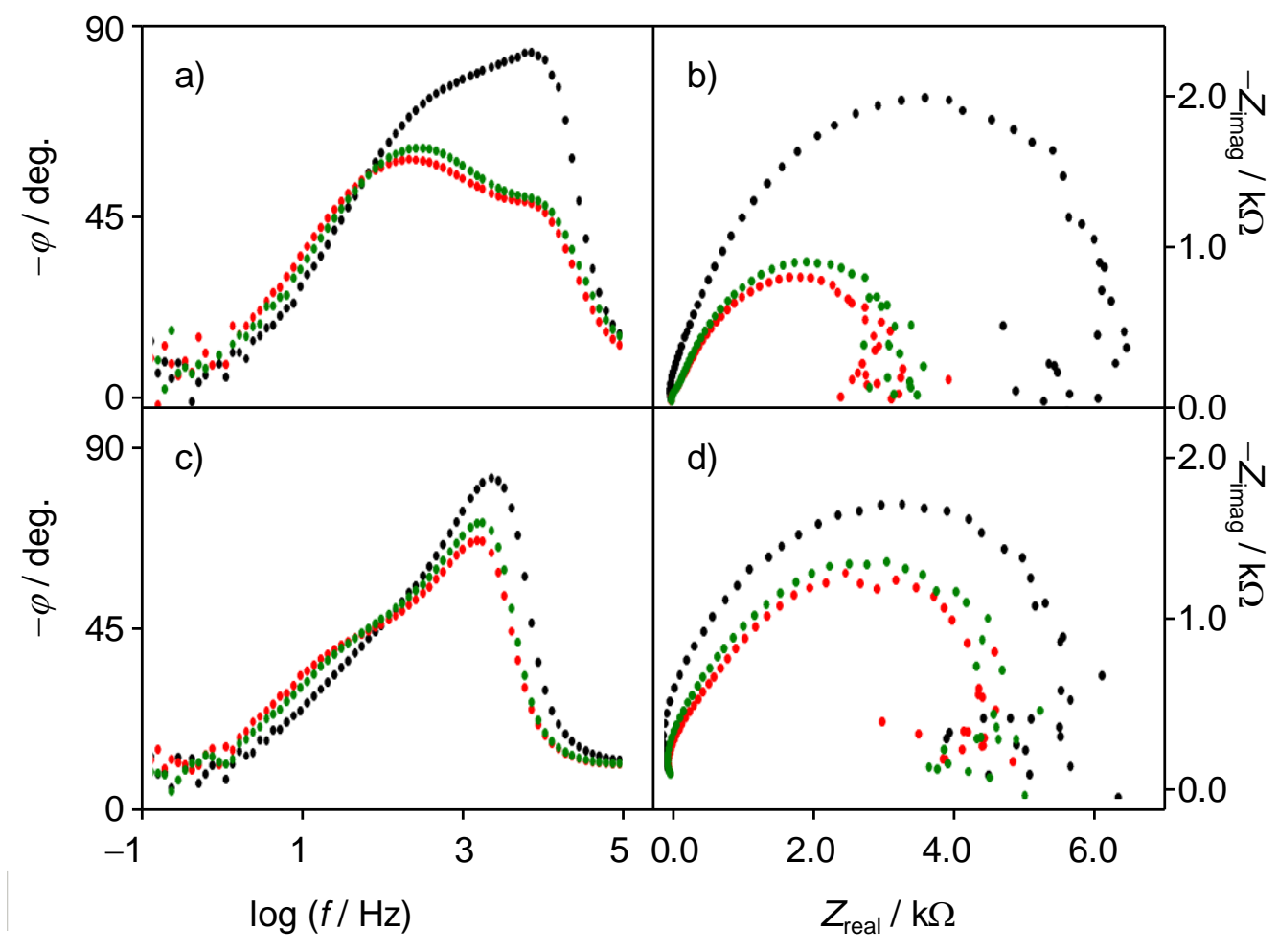


Figure 8.

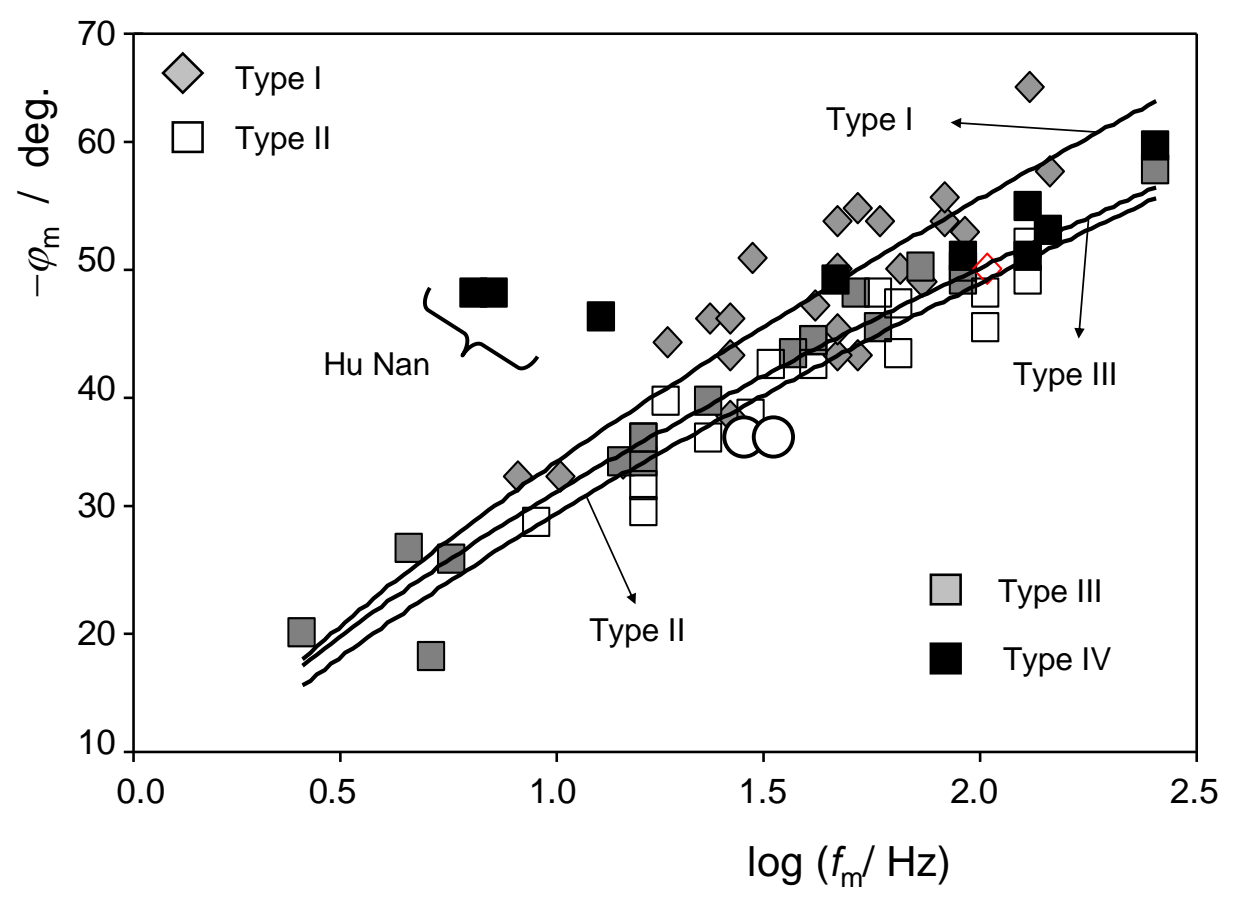


Supplementary Material
Click here to download Supplementary Material: TalantaMoneteCinese[Suppllnform][rev].doc

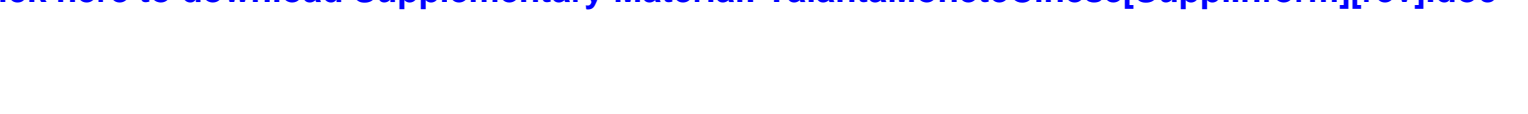

(1)

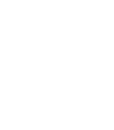
(

$\sqrt{2}$

(1) (1) . (1) (1) . . . . . . . . . . . . . 